\title{
Targeting PUMA/Bcl-xL interaction by new specific compounds to unleash apoptotic process in cancer cells.
}

Appala Venkata Ramana Murthy, ${ }^{\text {a,b }}$ Vennu Narendar, ${ }^{a}$ Nangunoori Sampath Kumar, ${ }^{\text {a }}$ Pasula Aparna, ${ }^{b}$ Anagani Kanaka Durga Bhavani, ${ }^{c *}$ Fabien Gautier, ${ }^{d, e, f}$ Sophie Barillé-Nion, ${ }^{d}$ Philippe Juin, ${ }^{\mathrm{d}}$ Paul Mosset, ${ }^{\mathrm{g}}$ René Grée, ${ }^{\mathrm{g}^{*}}$ Nicolas Levoin. ${ }^{\mathrm{h}^{*}}$

${ }^{a}$ Chemveda Life Sciences India Pvt. Ltd., \#B-11/1, IDA Uppal, Hyderabad-500039, Telangana, India

b Jawaharlal Nehru Technological University Hyderabad, Kukatpally, Hyderabad-500 085, Telangana, India

${ }^{c}$ Osmania University, Department of Chemistry, Hyderabad 500007, Telangana, India

${ }^{d}$ UMR 892 INSERM /6299 CNRS / Université de Nantes, Team 8 "Cell survival and tumor escape in breast cancer", Institut de Recherche Thérapeutique de l'Université de Nantes, 8 quai Moncousu, BP 70721, 44007 Nantes Cedex 1, France

e Institut de Cancérologie de l'Ouest, Centre de Lutte contre le Cancer René Gauducheau, Boulevard Jacques Monod, 44805 Saint Herblain-Nantes Cedex, France

${ }^{f}$ Plateforme IMPACT ${ }^{\circ}$, Biogenouest Institut de Recherche Thérapeutique de I'Université de Nantes, 8, quai Moncousu, BP 7072144007 Nantes Cedex 1, France.

${ }^{\mathrm{g}}$ Univ Rennes, CNRS, ISCR (Institut des Sciences Chimiques de Rennes), UMR 6226, F-35000 Rennes, France.

${ }^{\text {h }}$ Bioprojet-Biotech, 4 rue du Chesnay Beauregard, BP 96205, 35762 Saint Grégoire, France.

Corresponding author :

Dr.René Grée : E-mail: rene.gree@univ-rennes1.fr 


\section{Graphical Abstract}
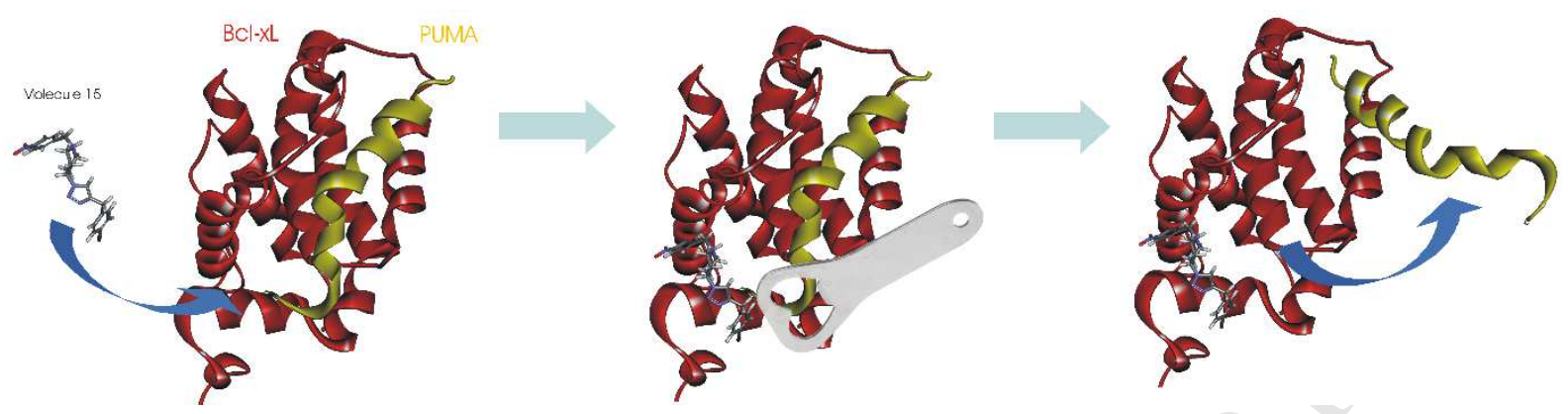

Highlights: in this paper, we report:

- The discovery of the first molecules able to displace the pro-apoptotic protein PUMA from its anti-apoptotic partner Bcl-xL in cancer cells.

- An appropriate Structure-Activity Relationships by preparing, and screening, a focused library of designed molecules.

- An extensive exploration of Bcl-xL and PUMA's behaviour in presence of our lead compound, using state of the art molecular modelling approaches.

- Following this analysis, we propose a new mechanism by which a small molecule can advantageously perturb the interaction of large protein partners, as sand in the gears. Such "bottle opener-type" strategy should be promising in the ever growing field of proteinprotein interactions.

\section{Keywords:}

- Cancer

- Protein-protein interactions

- PUMA

- $\quad B c l-x L$

- BRET

- Molecular modeling 


\section{Abstract}

We describe the first examples of small molecules able to disrupt the nanomolar interaction between the pro-apoptotic protein PUMA and its anti-apoptotic counterpart BCL-xL in malignant cells. Based on molecular modelling studies, we propose a rationale to this result, through a new "bottleopener"-type strategy which could be of general use in the area of protein-protein interaction studies.

\section{Introduction}

The evasion of apoptosis is one of the hallmarks of cancer [1]. The anti-apoptotic Bcl-2 family of proteins plays a key role in this context and the discovery of small molecules which are potent inhibitors of such proteins is a very active research area [2]. Bcl-xL is a major anti-apoptotic protein and as such, its targeting by inhibitory compounds is of crucial interest in treating cancers. This protein is frequently overexpressed in tumor cells, and this results in resistance to cell death induced by regular chemotherapies. Some BH3 mimetics compounds, named after the domain of proapoptotic proteins that interact with anti-apoptotic partners (BH3 domain), have been developed to overcome those resistances by antagonizing $\mathrm{Bcl}-\mathrm{xL}$, thereby releasing pro-apoptotic proteins and leading to mitochondrial outer membrane permeabilization and cell death. Though, efficacy of those molecules strongly depends on the nature of the interaction $\mathrm{Bcl}-\mathrm{xL}$ is engaged in. A recent publication [3] has shown that the pro-apoptotic BH3-only protein PUMA forms an interaction with $\mathrm{BCl}-\mathrm{XL}$ that is unsensitive to current BH3 mimetics molecules such as WEHI-539, a potent and selective $\mathrm{Bcl}-\mathrm{xL}$ inhibitor [4]. This resistance is mainly driven by molecular specificities of the BH3 domain of PUMA which binds with more affinity to the binding groove of $\mathrm{BCl}-\mathrm{XL}$ than other BH3-only proteins [5]. PUMA is an essential actor of cell death in response to many apoptotic signals, and the resistant trait of its interaction with $\mathrm{Bcl}-\mathrm{xL}$ negatively modulates the response of cancer cells to chemotherapies [6]. To the best of our knowledge there is no molecule, reported today, which is able to disrupt this $\mathrm{Bcl}-\mathrm{xL} / \mathrm{PUMA}$ interaction. Hence, there will be a significant therapeutic benefit in the development of new molecular compounds with improved affinity to disrupt this refractory interaction.

Our research programme is dealing with the design, synthesis and biological evaluation of new molecules able to override cancer cell outgrowth by promoting apoptosis. In this direction, we have recently developed several series of molecules suitable to disrupt the interactions between pro- 
apopototic proteins such as Bax and their anti-apoptotic counterparts such as Bcl-2 or Bcl-xL [7]. ${ }^{7} \mathrm{~A}$ few years back, a new derivative with a pyrimido-piperazine scaffold has been reported by Russu et al. [8] and the best molecule $\boldsymbol{A - 1}$ was a good inhibitor of $\mathrm{Bax} / \mathrm{Bcl}-\mathrm{xL}$ interaction with an $\mathrm{IC}_{50}=0.127$ $\mu \mathrm{Mol}$. Further, the high affinity of other benzyl-substituted piperazines, such as $\boldsymbol{A - 2}$, was shown to be due in large part to an hydrogen bond between the quinazoline nitrogen and Y101 [9].

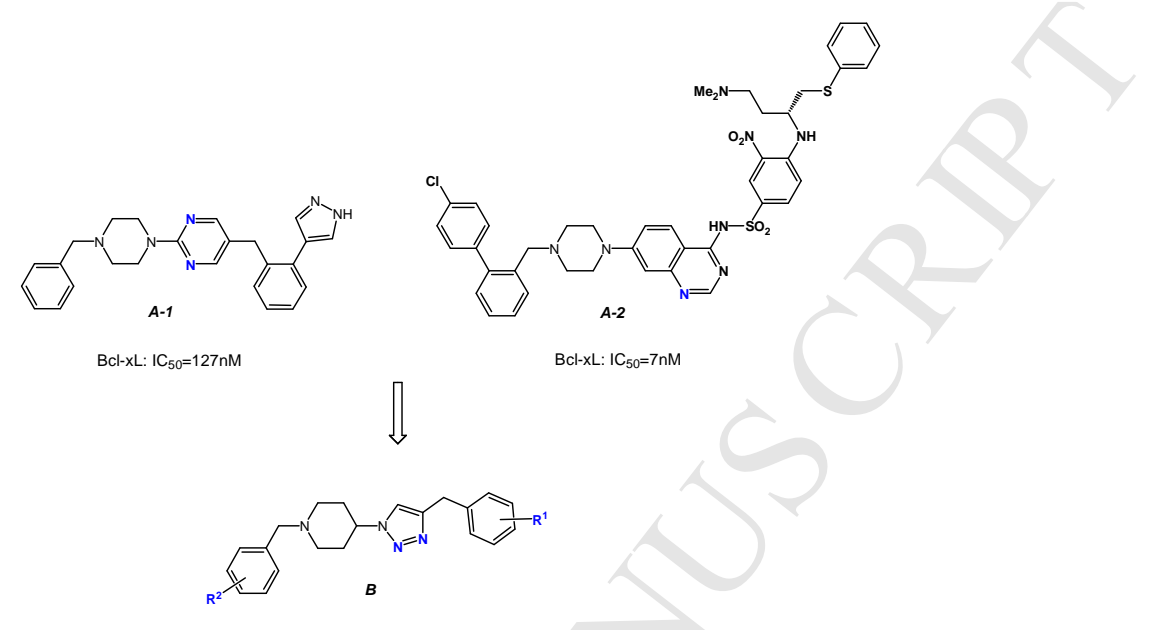

Scheme 1. Bcl-xL inhibitor molecules $\boldsymbol{A}$ from literature and our designed molecules $\boldsymbol{B}$.

However, 2D superimposition of both benzyl-type piperazines showed that the pyrimidine nitrogen of $\boldsymbol{A - 1}$ was not ideally positioned to make such a hydrogen bond, so we planed to use triazole as an alternative nitrogen-containing heteroaromatic. With two successive nitrogens and two possible orientations for the hydrogen bond, this group seemed promising to abide by this important interaction, leading to type- $\boldsymbol{B}$ molecules (Scheme 1). Furthermore, it is well recognized now that triazoles are very useful scaffolds in bioorganic and medicinal chemistry [10].

The goal of this paper is to report the synthesis of a focused library of type- $\boldsymbol{B}$ molecules and to test them as Bcl-xL inhibitors. Strikingly, we observed that several of these compounds were able to disrupt the PUMA/Bcl-xL interaction. They are the first molecules able to do so. A rationale will be proposed to explain this result, based on molecular docking and molecular dynamic studies. They suggested a "bottle-opener"-like mechanism, targeting the Bcl-XL/PUMA interaction at the level of the $C$-terminal part of PUMA.

\section{Results and discussion}

\section{Synthetic procedures}


To the best of our knowledge, no type- $\boldsymbol{B}$ molecules has been described to date and only few molecules relatively close to such structures have been reported [11]. Towards the type-B target molecules, we selected a convergent and flexible pathway as indicated in Scheme 2. It involved in last stage the coupling of benzyl bromides $\boldsymbol{D}$ with the type- $\boldsymbol{C}$ triazoles. Latter derivatives could be obtained by reaction of azide $\boldsymbol{E}$ with propargylic derivatives $\boldsymbol{F}$.

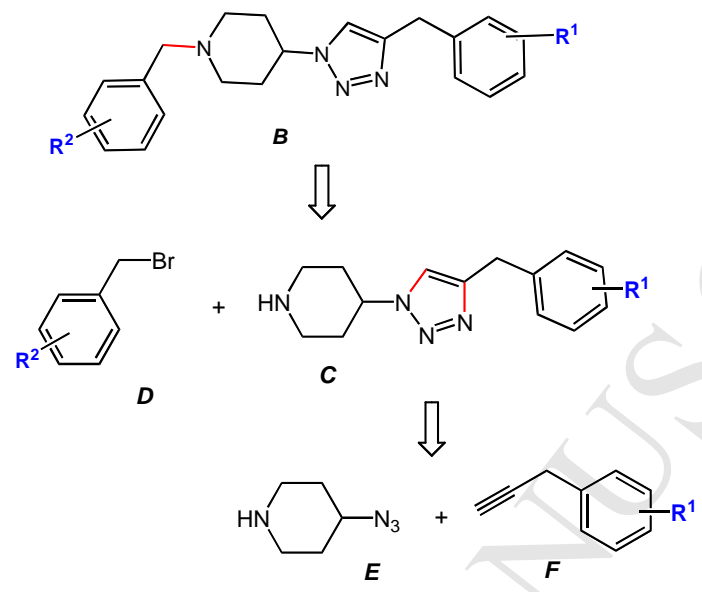

Scheme 2. Retrosynthetic analysis toward the target molecules

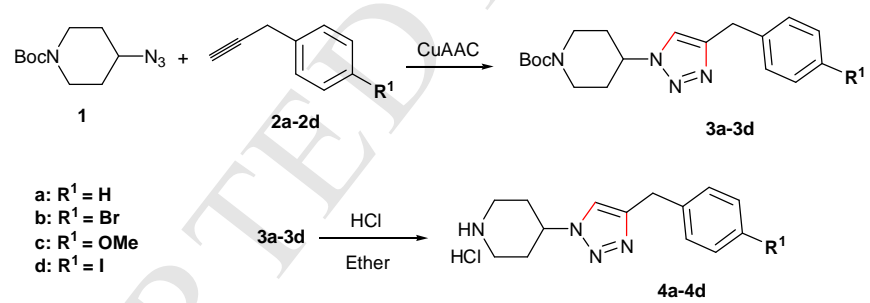

Scheme 3. Synthesis of intermediates 4

Thus, appropriate combinations of these key fragments $\boldsymbol{D}, \boldsymbol{E}$ and $\boldsymbol{F}$ should allow an efficient preparation of the designed chemical library of target molecules. The synthesis of the intermediates $\mathbf{4}$ is described in Scheme 3. It combines the known azide $\mathbf{1}$ [12], and the also known, alkynes 2a-2d [13].

The click-type reactions, [14] between 1 and $\mathbf{2}$ afforded the triazoles 3a-3c, used directly for the next step. A final deprotection gave the desired intermediates $\mathbf{4 a - 4 c}$, as hydrochlorides, in satisfactory overall yields (55-61 \% for the two steps).

Having these derivatives in hand, the stage was set for the preparation of the first target molecules (Scheme 4). Condensation of the triazoles $4 a-4 c$ with five representative benzyl bromide derivatives 
5a-5e in dichloromethane at reflux in the presence of triethylamine afforded the first fifteen target molecules 6-20 in fair to excellent yields (Table 1).

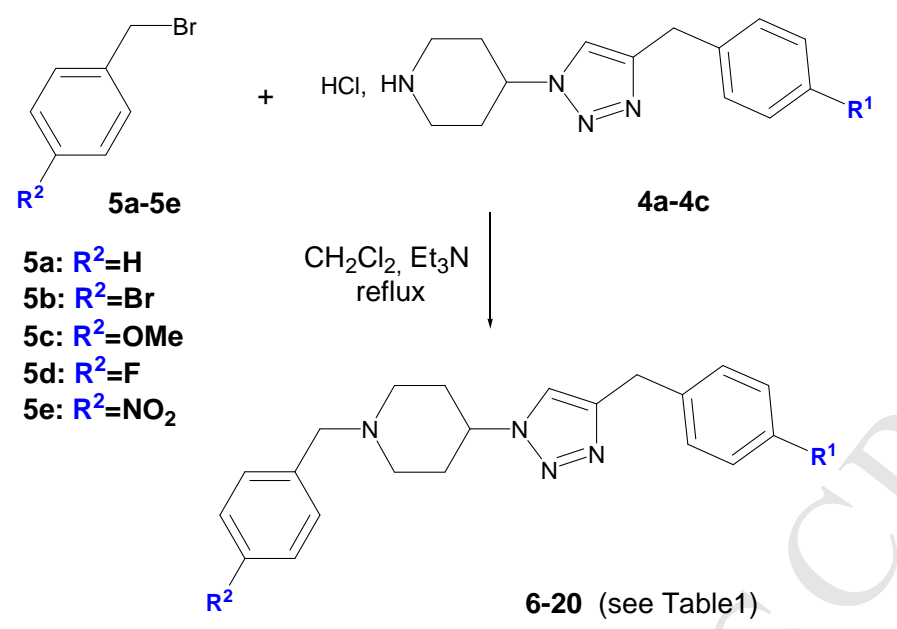

Scheme 4. Synthesis of the chemical library compounds 6-20 (Table 1, entries 1 to 15).

In order to complete the Structure-Activity-Relationships studies, and explore in more depth the roles of the nature of $R^{1}$ and $R^{2}$ groups, a few more molecules were prepared. First, concerning the $R^{2}$ group on the benzyl-piperidino moiety, three compounds with primary amino groups 21-23 have been prepared by reduction of the previous nitro derivatives 10, 15 and $\mathbf{2 0}$ (Scheme 5).

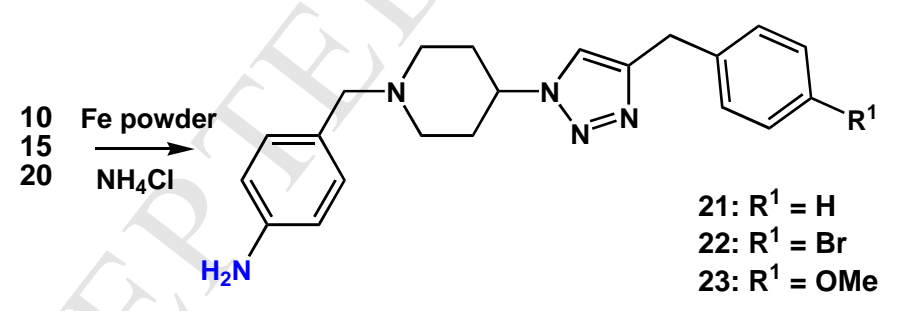

Scheme 5. Preparation of amino derivatives 21-23 (Table 1, entries 16 to 18).

Further, condensation of triazole $\mathbf{4 b}$ with benzyl bromides $\mathbf{5} f$ and $\mathbf{5 g}$ afforded the derivatives $\mathbf{2 4}$ and $\mathbf{2 5}$ where the nitro group has been shifted to the meta and ortho positions, respectively (Scheme 6). 


\begin{tabular}{|c|c|c|c|c|}
\hline Entry & Compound & $\mathbf{R}^{1}$ & $\mathbf{R}^{2}$ & Yield (\%) \\
\hline 1 & 6 & $\mathrm{H}$ & $\mathrm{H}$ & 68 \\
\hline 2 & 7 & $\mathrm{H}$ & $\mathrm{Br}$ & 59 \\
\hline 3 & 8 & $\mathrm{H}$ & OMe & 62 \\
\hline 4 & 9 & $\mathrm{H}$ & $\mathrm{F}$ & 55 \\
\hline 5 & 10 & $\mathrm{H}$ & $\mathrm{NO}_{2}$ & 50 \\
\hline 6 & 11 & $\mathrm{Br}$ & $\mathrm{H}$ & 49 \\
\hline 7 & 12 & $\mathrm{Br}$ & $\mathrm{Br}$ & 48 \\
\hline 8 & 13 & $\mathrm{Br}$ & OMe & 46 \\
\hline 9 & 14 & $\mathrm{Br}$ & $F$ & 50 \\
\hline 10 & 15 & $\mathrm{Br}$ & $\mathrm{NO}_{2}$ & 68 \\
\hline 11 & 16 & OMe & $\mathrm{H}$ & 45 \\
\hline 12 & 17 & OMe & $\mathrm{Br}$ & 51 \\
\hline 13 & 18 & OMe & OMe & 49 \\
\hline 14 & 19 & OMe & $F$ & 48 \\
\hline 15 & 20 & OMe & $\mathrm{NO}_{2}$ & 61 \\
\hline 16 & 21 & $\mathrm{H}$ & $\mathrm{NH}_{2}$ & 65 \\
\hline 17 & 22 & $\mathrm{Br}$ & $\mathrm{NH}_{2}$ & 62 \\
\hline 18 & 23 & OMe & $\mathrm{NH}_{2}$ & 58 \\
\hline 19 & 24 & $\mathrm{Br}$ & $\mathrm{O}-\mathrm{NO}_{2}$ & 72 \\
\hline 20 & 25 & $\mathrm{Br}$ & $m-\mathrm{NO}_{2}$ & 74 \\
\hline 21 & 26 & $\mathrm{Br}$ & $p-\mathrm{CO}_{2} \mathrm{Me}$ & 68 \\
\hline 22 & 27 & $\mathrm{Br}$ & $p-\mathrm{CO}_{2} \mathrm{H}$ & 79 \\
\hline 23 & 28 & $I$ & $\mathrm{NO}_{2}$ & 70 \\
\hline 24 & 29 & $\mathrm{CCH}$ & $\mathrm{NO}_{2}$ & 63 \\
\hline
\end{tabular}

Table 1. Preparation of triazoles 6-29

On the other hand, starting from the benzyl bromide with an ester group in para position $\mathbf{5 h}$, two more target molecules $\mathbf{2 6}$ and $\mathbf{2 7}$ have been prepared in good yields by the same route. Finally, in order to obtain a complementary information about the role of the $\mathrm{R}^{1}$ group, the iodo derivative $\mathbf{2 8}$ 
has been prepared similarly by reaction of $\mathbf{4 d}$ with $\mathbf{5 e}$. Then the alkyne analog, $\mathbf{2 9}$, has been obtained by a Sonogashira-type reaction starting from 28.

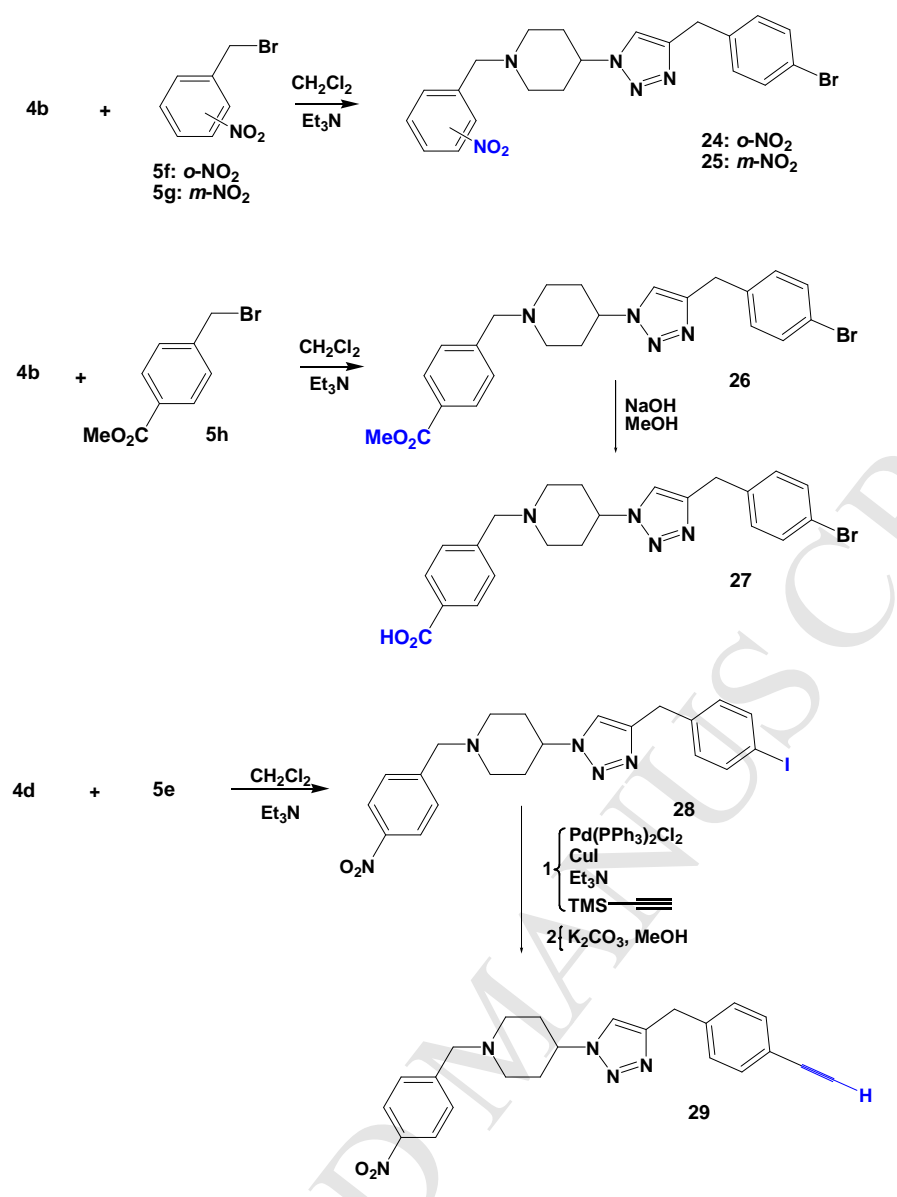

Scheme 6. Preparation of derivatives 24-29 (Table 1, entries 19 to 24).

All compounds of this chemical library have their spectral and analytical data fully consistent with the proposed structures.

\section{Biological studies: BRET experiments in live cancer cells}

Biological evaluation of these compounds were obtained by BRET (Bioluminescence Resonance Energy Transfer) measurements in cancer cells on PUMA/Bcl-xL interaction. All molecules from the previous focused chemical library (Table 1 ) have been tested but only three compounds $(\mathbf{1 5}, \mathbf{2 8}$ and 29) demonstrated a significant effect on the BRET signals. Compared to a known Bcl-xL inhibitor, WEHI-539, the dose response curves in figure 1-a clearly indicates that these molecules are more efficient to disrupt this interaction than WEHI-539 which was previously found to be ineffective in this case [3]. Strikingly, these molecules show the same ability to kill cells than that of WEHI-539, with an $\mathrm{EC}_{50}$ measured in Trypan Blue enumeration performed in MCF-7 cell line of nearly $3 \mu \mathrm{M}$ (fig. 
1-b), summarizing the fact that apoptotic process involves a number of different interactions that engage $\mathrm{Bcl}-\mathrm{xL}$, which could be differentially targeted by each molecule. To further assess the apoptotic nature of the response, we used flow cytometry analysis to illustrate the cleavage of caspase 3 , reflecting its activation, and the release of cytochrome $\mathrm{C}$, signature of mitochondria outer membrane permeabilization, two main traits of mitochondrial apoptosis, as exemplified by the results obtained for cells treated with molecule 15 (fig. $1 \mathrm{c}$ ).

a

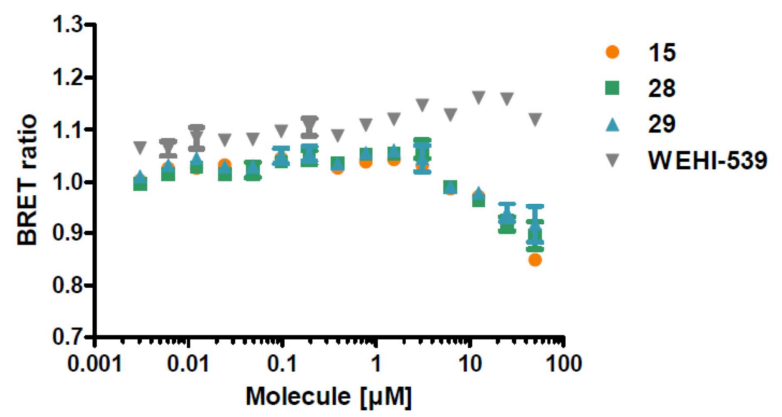

c)

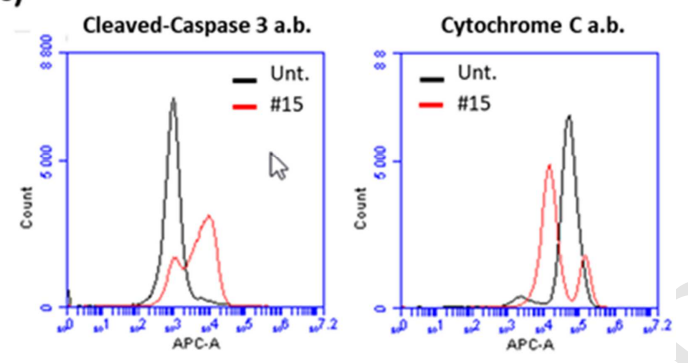

b

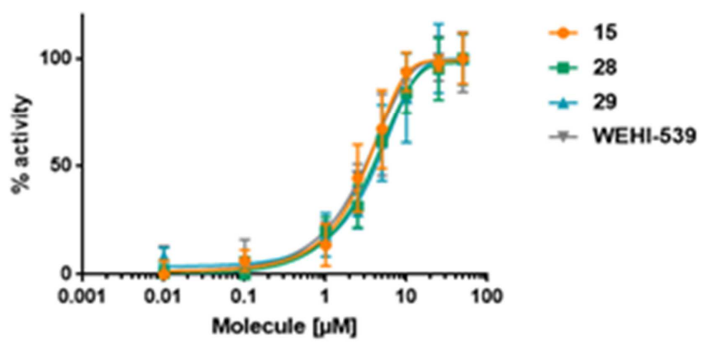

Fig. 1 a) BRET based dose response curves of compounds 15, 28, and 29 on PUMA/Bcl-xL interaction in live cancer cells. WEHI-539 was used as reference antagonist for Bcl-xL. b) Dose response curves of the corresponding molecules, estimated after counting of dead cells stained with Trypan Blue. c) Flow cytometry analysis of caspase 3 cleavage (left) and cytochrome $\mathrm{C}$ release (right), using anti cleaved caspase 3 and anti cytochrome $C$ antibody respectively, after $24 \mathrm{~h}$ treatment with compound 15 at $10 \mu \mathrm{M}$.

These results establish, for the first time, that small molecules are able to disrupt this strong BclXL/PUMA interaction. They also highlight a key role for the substituents $R^{1}$ and $R^{2}$ in terminal positions of these type- $\boldsymbol{B}$ structures. First, the para nitro substituent on the left side of the molecules ( $R^{2}$ group) proved to be crucial for the activity since it displacement in meta or ortho position gave compounds with very low (compound 25), or no activity (molecule 24). Furthermore it cannot be replaced by another electron-withdrawing group such as an ester or an acid. On the other hand, compounds with $\mathrm{R}^{2}=$ hydrogen, bromo-, fluoro-, amino or methoxy substituents were inactive as well. Then, on keeping $\mathrm{R}^{2}=p-\mathrm{NO}_{2}$, we didn't observe any significant difference between the three 
active molecules $(\mathbf{1 5}, 28$ and $\mathbf{2 9})$, indicating that the involved lipophilic pocket from the Bcl-xL protein should be large enough to adjust to substituents with various size in this $R^{1}$ position.

\section{Exploration of the compound's binding mode by molecular simulations}

In the very large cavity of $\mathrm{Bcl}-\mathrm{xL}\left(1871 \AA^{3}\right)$, molecular docking of compound 15 suggested two possible binding sites. The first corresponds roughly to the arylpiperazine's site of co-crystallized molecule A-2 (PDB: 3QKD), the second site lies between Y101 and Y195, at the mouth of the above cavity (Supplementary information Figure 1). Surprisingly, the basic piperidine doesn't form any interaction in this former binding mode, whereas the piperidine could form a salt bridge with either E92 or E96 in the later. A consensus emerged from the scoring functions in favour of the second binding site, shown in Figure 2. In addition to the calculated affinity, this binding mode is further supported by two considerations: (i) given the importance of the desolvation energy of cations, its seems unlikely that the piperidine of a small molecule could not form any interaction with the protein, (ii) we previously identified the second site as the hot spot of binding for small molecules on Bcl-xL [7d]. So it seems that large ligands, such as the cocrystallized compound $\boldsymbol{A - 2}$ are able to form other interactions that direct them towards site 1 instead of site 2 . In this site, the ligand lies in a horseshoe-shaped cavity around Y195, lined with E96, F97, N136, W137, F191 and Y195. Its piperidine forms a salt bridge with E96. Nitrophenyl makes a $\pi$-stacking interaction with Y195 and bromophenyl with W137. An indirect hydrogen bond bridged by a water molecule is probable between the nitro group and E92, and between the triazole and Y101.

This binding mode is consistent with the SAR of our series: on $R^{1}$ side, there is enough place for larger substituent than para-bromo, such as para-iodo or para-alkyne. Moreover, the polarizability of these groups make them suitable for such a solvent-exposed cavity. The nitro substituent's position of the other phenyl is more restrictive: the indirect hydrogen bond seems still possible with meta- or orthonitro, but the interaction energy is lower. The benzyl group undergoes a rotation to maintain the interaction of the meta-nitro, while the ortho-nitro is a bit more penalized because of the increasing distance between the interacting groups. 


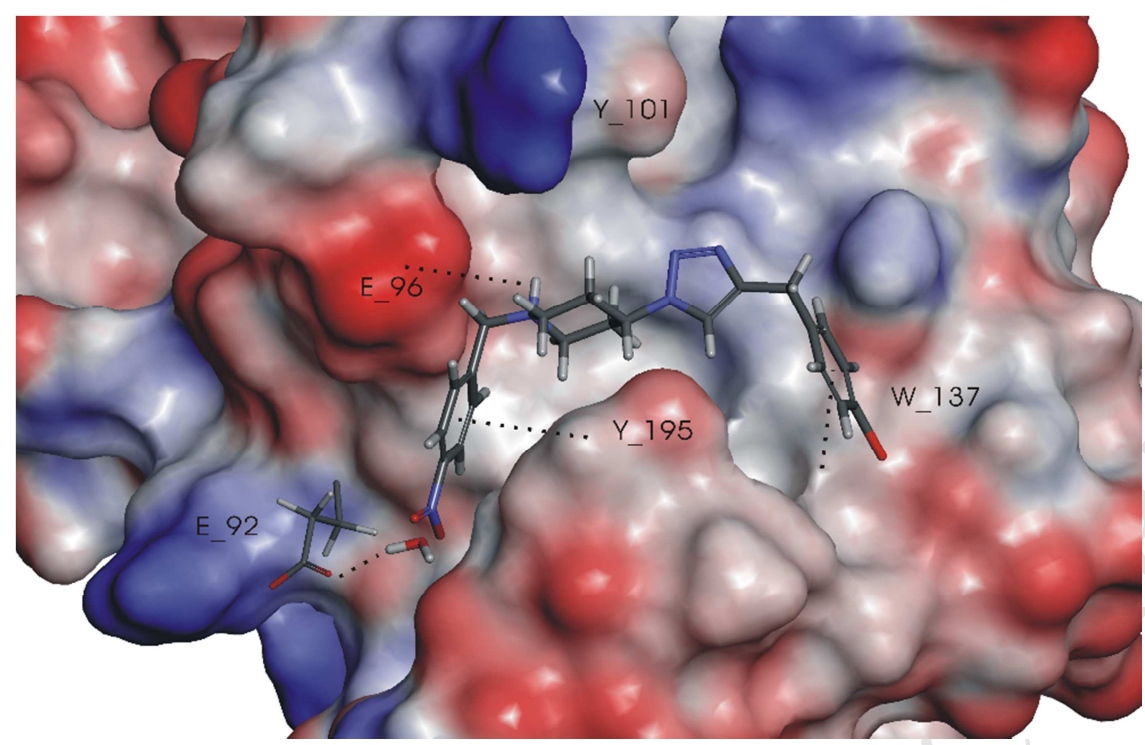

Fig. 2. Proposed binding mode for compound 15. The ligand forms a salt bridge with E96. Nitrophenyl makes a $\pi$-stacking interaction with Y195 and bromophenyl with W137. Indirect hydrogen bond bridged by a water molecule is probable between the nitro group and E92, as illustrated, and between the triazole and Y101 (not shown).

The ability of compound $\mathbf{1 5}$ to displace PUMA was scrutinized in light of experimental structures of Bcl-xL/PUMA complexes [15]. Superimposition of the 20 NMR-derived conformations showed that PUMA is somewhat flexible, particularly its $C$-terminal $(C t)$ part. In fact, only the central portion of the peptide is very stable and tightly bound (residues 133 to 150 , Fig. 3 ).

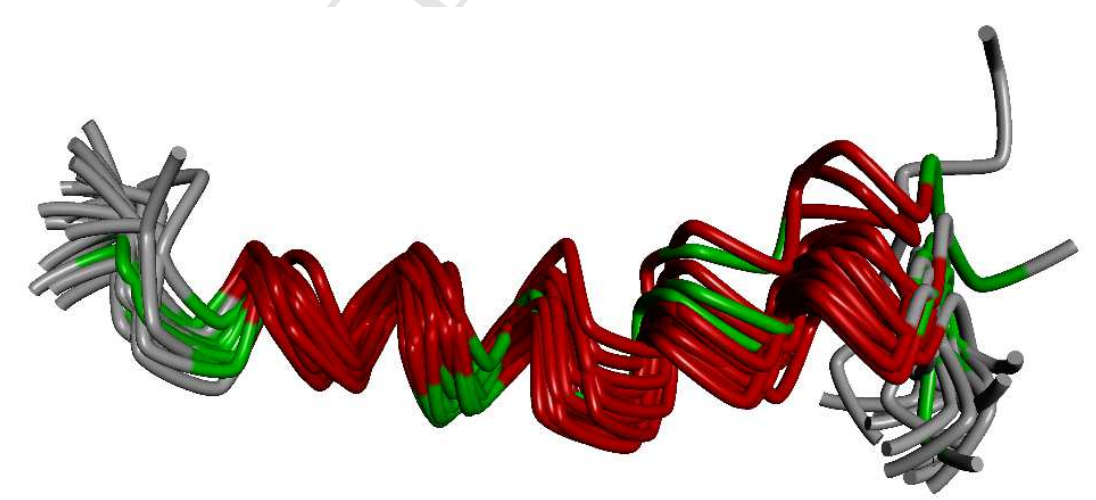




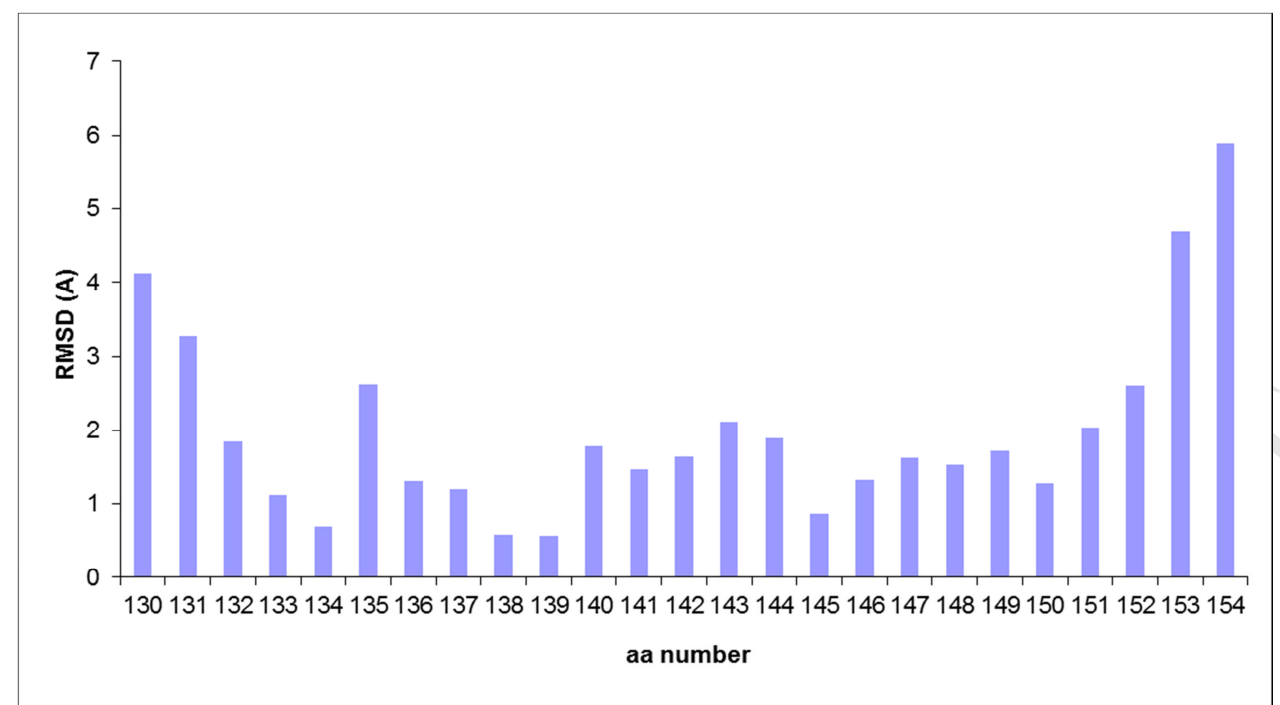

Fig. 3. Superimposition of the 20 NMR-derived structures of PUMA, complexed with Bcl-xL (PDB: $2 \mathrm{M04}$, top). The $\alpha$-helix is oriented from $\mathrm{Nt}$ (left) to $\mathrm{Ct}$ (right). The bottom diagram shows the Root Mean Square Deviation (RMSD) of each PUMA's amino acid, calculated from their mean position (in $\AA)$.

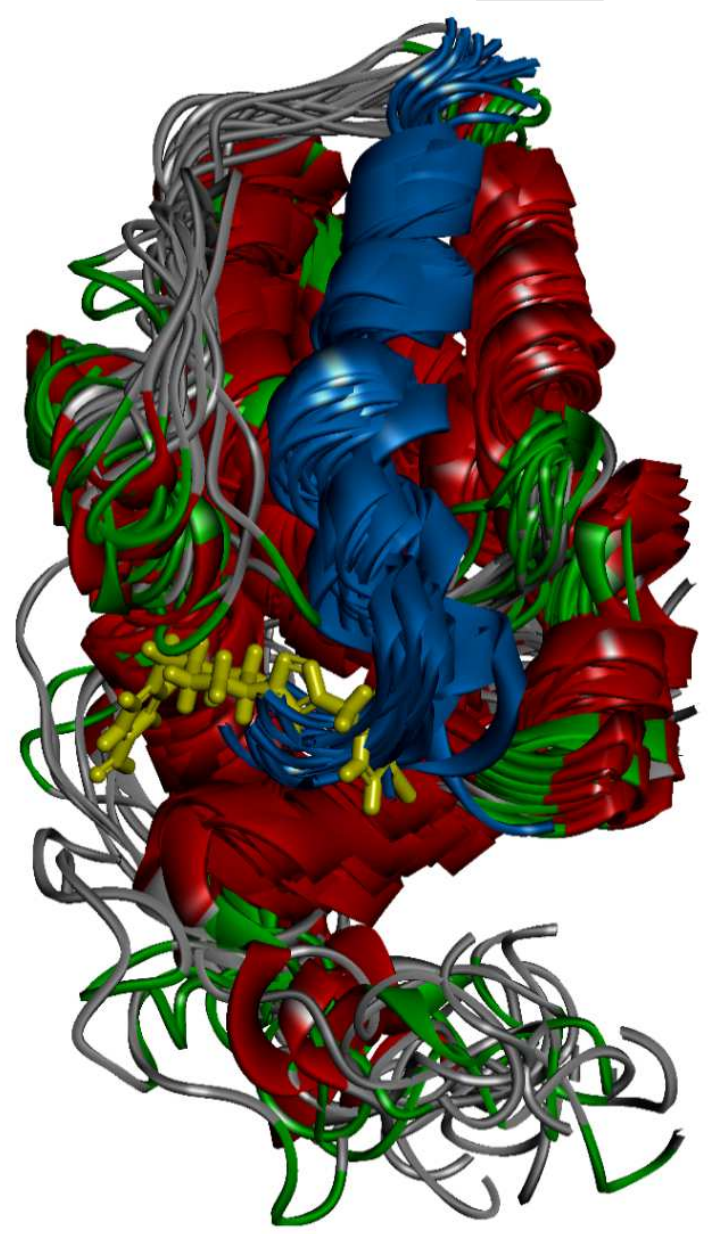

Fig. 4. The supposed position of compound 15 (yellow sticks) in the 20 NMR-derived structures of PUMA (blue helices), complexed with Bcl-xL (red). 
Interestingly, molecular modelling analyses previously suggested that our new series of $\mathrm{Bcl}-\mathrm{xL}$ inhibitors bind on a cavity located on PUMA's Ct surroundings [7c,7d], and compound 15 binding was also modelled on this pocket. The supposed binding site is not completely included in PUMA's crevice, but rather located on its feet (Fig. 4).

\begin{tabular}{lccc} 
& & \multicolumn{2}{c}{$\begin{array}{c}\text { PUMA's velocity } \\
(\AA / \mathrm{As})\end{array}$} \\
& $\mathrm{n}$ & model 1 & model 2 \\
binary complex & 3 & 0,08 & 0,09 \\
ternary complex & 4 & 0,31 & 0,23
\end{tabular}

Table 2. PUMA's motion was assessed through RMSD from the starting conformation. The velocity calculation used an exponential curve (model 1) or a linear fitting (model 2).

Velocities are the mean of 3 and 4 molecular dynamics experiments, respectively for binary and ternary complex (Fig. 5a and 5b).

Consequently, PUMA and compound $\mathbf{1 5}$ binding could be not strictly competitive, and one can envisage the existence of a transient ternary complex. In this way, compound 15 binding could accentuate intrinsic PUMA's movements, ending up in its unbinding. We performed multiple molecular dynamics experiments to test this hypothesis. The simulation showed that compound 15 binding combined with a 2-fold increase in PUMA's motion within Bcl-xL binding site (Table 2). Even if our simulations were too short to observe a complete unbinding of PUMA, a process which is certainly at a much higher timescale [16], the restlessness that we observed represents certainly the first step of the dissociation. 

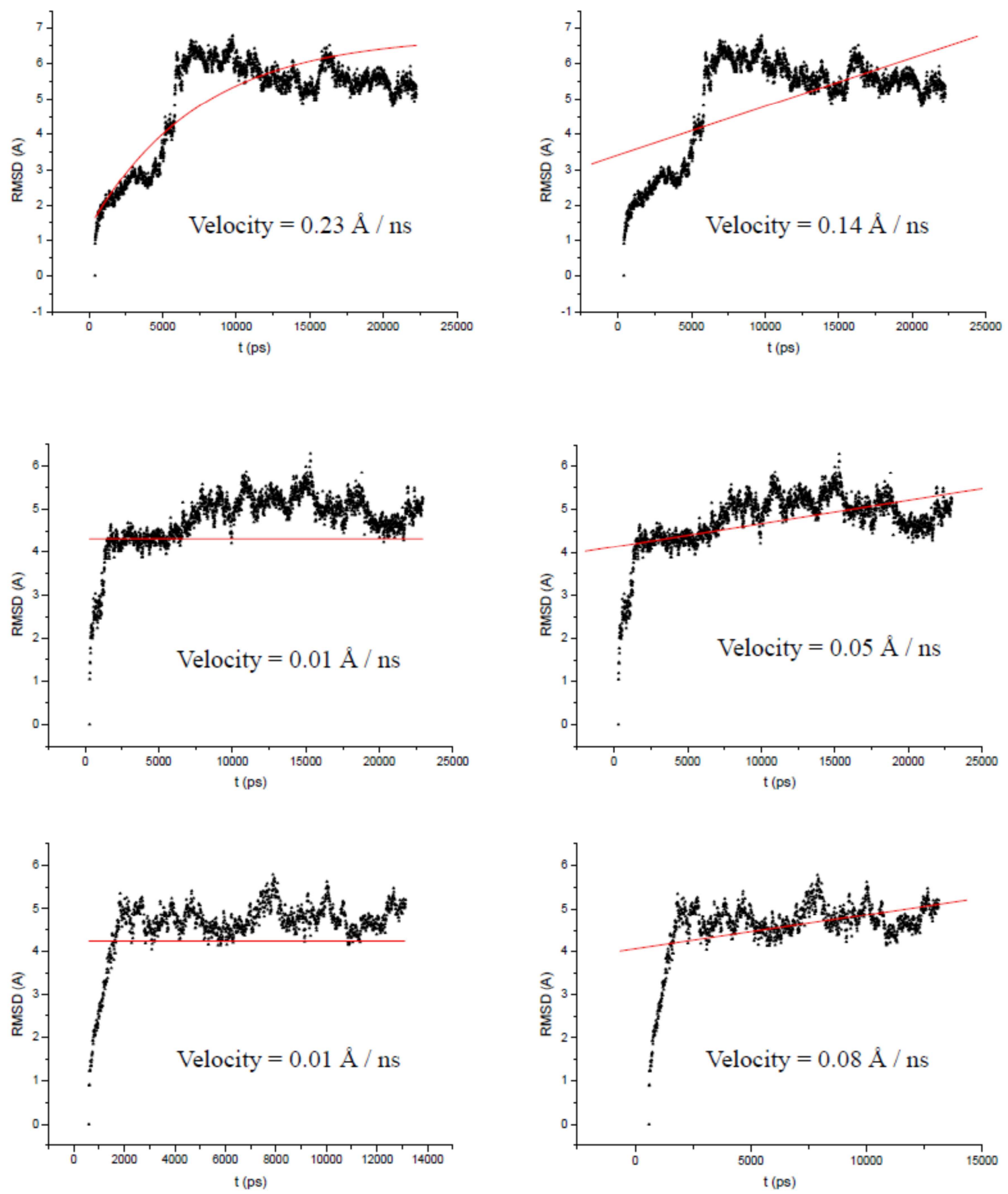

Fig. 5a: Modeling of the RMSD curve for the binary complex. Exponential fitting (left) and linear fitting (right) 

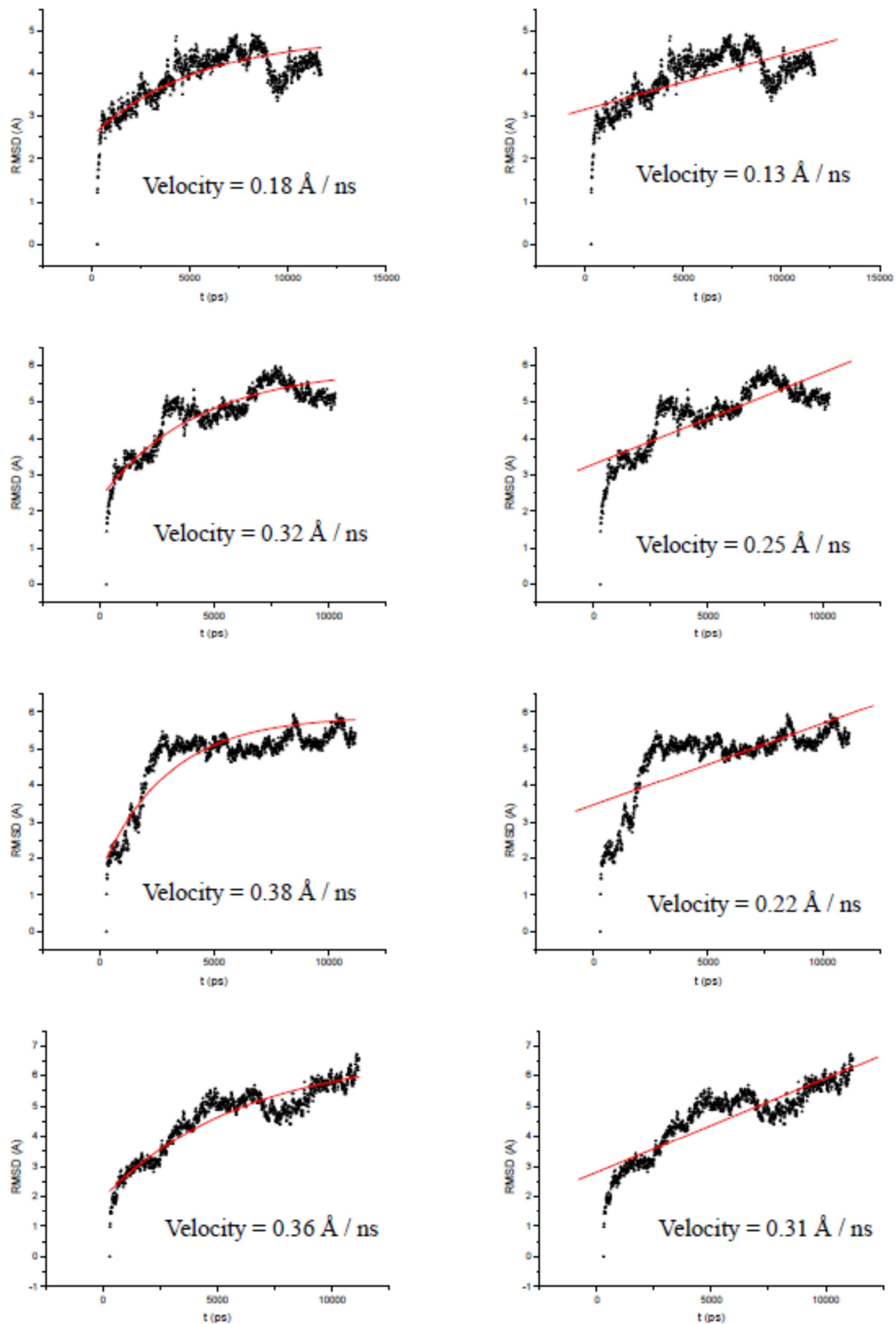

Fig. 5b. Modeling of the RMSD curve for the ternary complex. Exponential fitting (left) and linear fitting (right) 


\section{ACCEPTED MANUSCRIPT}

Moreover, we also noticed a partial unfolding of Bcl-xL-bond PUMA during the simulation (Fig.6 and Fig. 7). Again, this behaviour might represent the beginning of PUMA's unbinding, since PUMA is completely disordered in the free form, and undergoes a helical structuring only meanwhile $\mathrm{Bcl}-\mathrm{xL}$ binding [15].
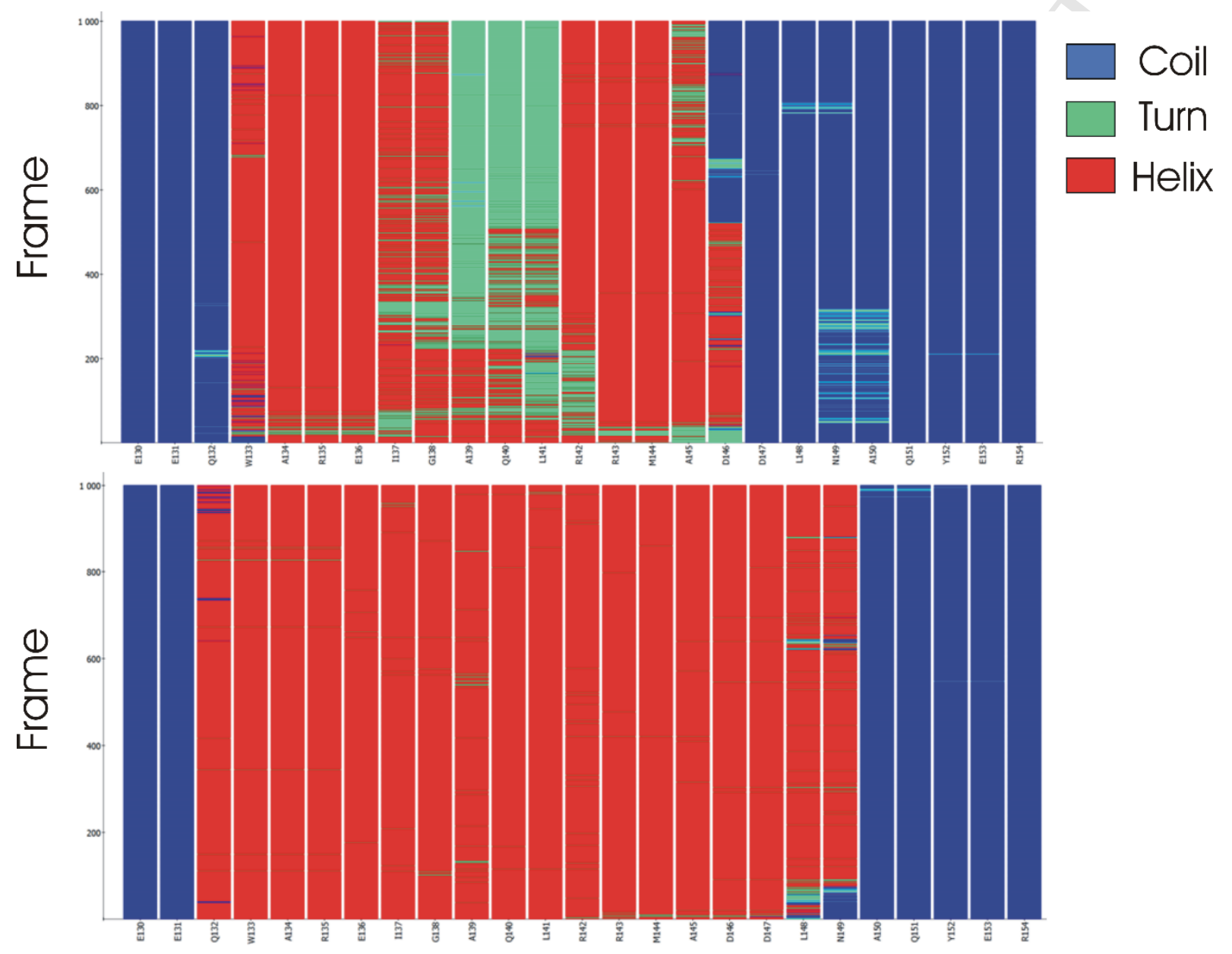

Amino acid

Fig. 6. top PUMA's secondary structure during molecular dynamics of the ternary complex (Bcl$\mathrm{xL} / \mathrm{PUMA} /$ compound 15). Bottom PUMA's secondary structure during molecular dynamics of the binary complex (Bcl-xL/PUMA). The heat map displays secondary structure (blue: unstructured, green: turn, red: helix) of PUMA's residue (X axis, from E130 to R154) during the simulation ( $Y$ axis for the time, here snapshots of the simulation). 


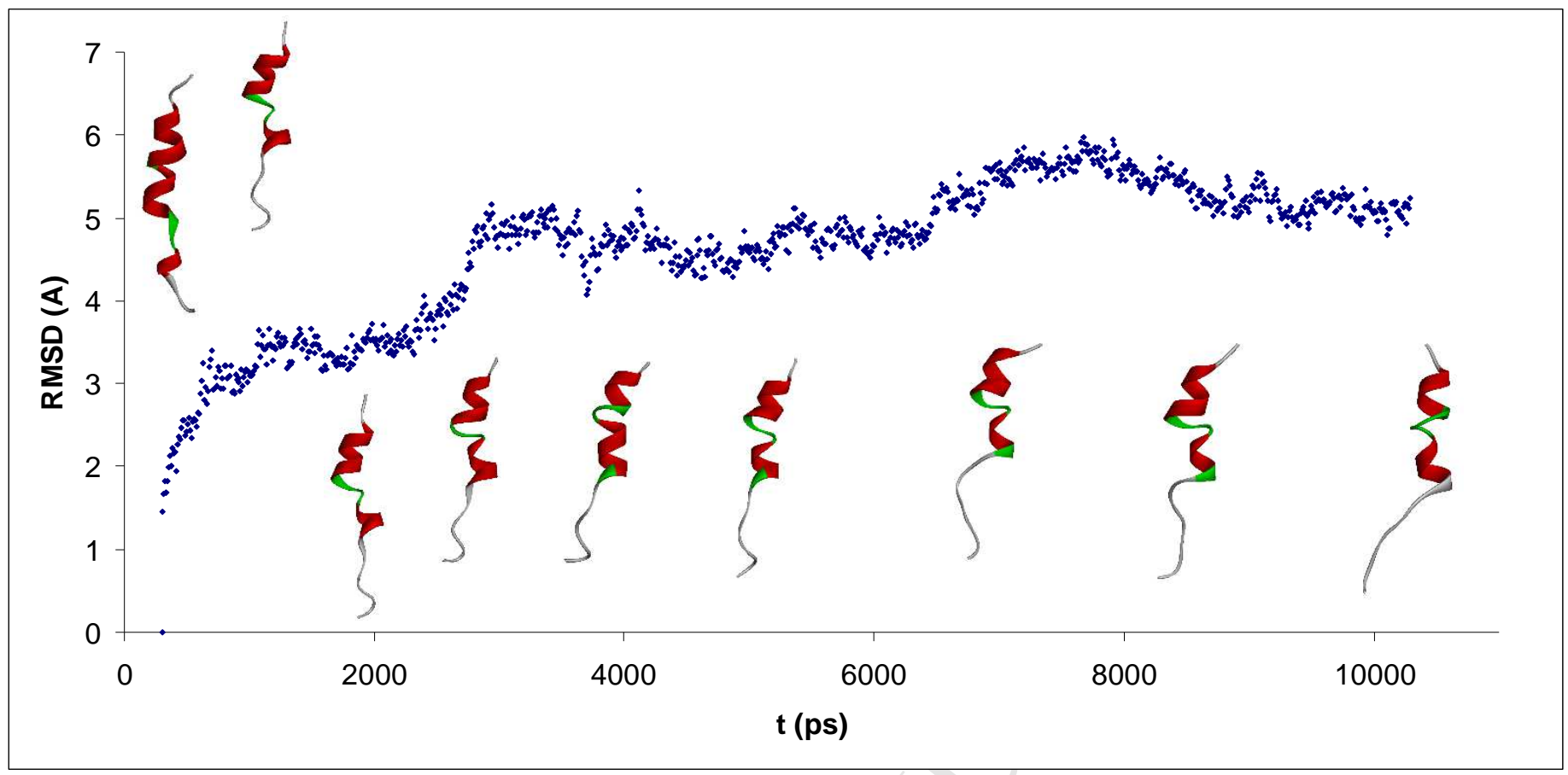

Fig. 7. Snapshots of PUMA during a molecular dynamics experiment of the ternary complex, showing its partial unfolding. As noticed in NMR analysis (cf text), PUMA's Ct is particularly flexible. One can also observe the gradual unfolding of the middle of the helix, a premice of PUMA's unbinding.

Collectively, molecular modelling experiments allowed the understanding of the distinctive features of compound 15. It seems not to simply compete with PUMA's binding, but rather to accentuate PUMA's intrinsic instability, thereby accelerating its unbinding.

\section{Experimental}

\section{Chemical Synthesis}

\section{General information:}

All anhydrous reactions were performed in heat gun-dried round-bottomed flasks under a dry argon or nitrogen atmosphere. Air and moisture-sensitive compounds were introduced via syringes or cannulae, using standard inert atmosphere techniques. In addition, the gas stream was passed through glass cylinder filled with $\mathrm{P}_{2} \mathrm{O}_{5}$ to remove any traces of residual moisture. Reactions were monitored by thin layer chromatography (TLC) using E. Merck silica gel 
plates and components were visualized by illumination with short wavelength UV light and/or staining (ninhydrine or basic $\mathrm{KMnO}_{4}$ ). All aldehydes were distilled right before use. All benzyl bromides and other reagents were used as they received from commercial suppliers, unless otherwise noted. THF and $\mathrm{Et}_{2} \mathrm{O}$ were dried over sodium-benzophenone and distilled prior to use. Anhydrous $\mathrm{CH}_{2} \mathrm{Cl}_{2}$ was prepared by refluxing in the presence of $\mathrm{CaH}_{2}$ and distilled right before use unless otherwise noted.

${ }^{1} \mathrm{H}$ NMR spectra were recorded at 300 and $400 \mathrm{MHz}$, and ${ }^{13} \mathrm{C}$ NMR spectra at 75 and 100 $\mathrm{MHz}$, respectively in $\mathrm{CDCl}_{3}$ or $\mathrm{DMSO}-\mathrm{d}_{6}$ using TMS (tetramethylsilane) as an internal standard. All triazole compounds were purified by flash column chromatography on neutral alumina unless otherwise noted.

Preparation of compounds 4a-4d: To a stirred solution of alkyne 2a-2d (17.24 mmol, 1.0 equiv) and tert-butyl 4-azidopiperidine-1-carboxylate (compound 1) ( $8.62 \mathrm{mmol}, 0.5$ equiv) in a 1:1 mixture of $t$-butanol and water $(100 \mathrm{~mL})$ was added copper sulfate pentahydrate $(1.724$ mmol, 0.1 equiv) and sodium ascorbate $(5.172 \mathrm{mmol}, 0.3$ equiv) at room temperature. The resulting mixture was stirred overnight. After completion of the reaction, the reaction mixture was diluted with ethyl acetate and water $(50 \mathrm{~mL}$ each). Organic layers were separated and washed with a $5 \%$ ammonium hydroxide solution $(50 \mathrm{~mL})$ and followed by brine $(50 \mathrm{~mL})$. The combined organic layers were dried over $\mathrm{Na}_{2} \mathrm{SO}_{4}$. The solvent was evaporated under reduced pressure to get the crude product, which was washed with $n$-hexane to get required compound as light brown solid. To the stirred solution of above obtained compound in ether $(10 \mathrm{~mL})$ was slowly added $2 \mathrm{M} \mathrm{HCl}$ in diethyl ether $(10 \mathrm{~mL})$ at $0{ }^{\circ} \mathrm{C}$. The reaction mixture was stirred for $16 \mathrm{~h}$ at room temperature. The formatted solid materials were filtered. The solvents were evaporated under vacuum and the residue was triturated with $n$-hexane and decanted twice to get a solid triazole $\mathbf{4 a - 4 d}$ as a hydrochloride salt $(\mathbf{4 a}: 61 \%, \mathbf{4 b}: \mathbf{6 0 \%} \mathbf{4 c}$ : $57 \%$ and $\mathbf{4 d}$ : $55 \%$ yield).

4-(4-Benzyl-1H-1,2,3-triazol-1-yl)piperidine hydrochloride (4a): ${ }^{1} \mathrm{H}$ NMR (400 MHz, DMSO- $\mathrm{d}_{6}$ ): $\delta$ 9.50-9.15 (broad envelope which topped at 9.25 ppm, 1H), 9.15-8.90 (broad envelope which topped at $9.05 \mathrm{ppm}, 1 \mathrm{H}), 7.93$ (broad s, 1H), 7.34-7.24 (m, 4H), 7.20 (ddt, $J=$ 7.4, 6.3, $\left.1.6 \mathrm{~Hz}, \mathrm{H}_{\mathrm{para}}, 1 \mathrm{H}\right), 4.78$ (tt, $\left.J=10.6,4.4 \mathrm{~Hz}, 1 \mathrm{H}\right), 4.00(\mathrm{~s}, 2 \mathrm{H}), 3.43-3.31$ (very broad d centered at $3.37 \mathrm{ppm}, J=12.8 \mathrm{~Hz}, 2 \mathrm{H}$ ), 3.15-3.00 (very broad q centered at $3.08 \mathrm{ppm}, J \approx$ $11.4 \mathrm{~Hz}, 2 \mathrm{H}), 2.32-2.13$ (m, 4H). ${ }^{13} \mathrm{C}$ NMR (100 MHz, DMSO-d 6 ): $\delta 145.84,139.37,128.41$ 
(2C), 128.37 (2C), 126.09, 121.03, 54.05, 41.82 (2C), 31.09, 28.41 (2C). 4a is a known compound [19].

4-(4-(4-Bromobenzyl)-1H-1,2,3-triazol-1-yl)piperidine hydrochloride (4b): ${ }^{1} \mathrm{H}$ NMR (300 MHz, DMSO-d 6 ): $\delta$ 9.35-9.05 (broad envelope which topped at $9.14 \mathrm{ppm}, 1 \mathrm{H}$ ), 9.07-8.75 (broad envelope which topped at 8.97 and 8.94 ppm, 1H), 7.94 (s, 1H), 7.49 (half part of an $\mathrm{A}_{2} \mathrm{X}_{2}$ system, 2H), 7.23 (half part of an $\mathrm{A}_{2} \mathrm{X}_{2}$ system, $2 \mathrm{H}$ ), 4.77 (tt, $J=10.6,4.5 \mathrm{~Hz}, 1 \mathrm{H}$ ), 3.98 (s, 2H), 3.45-3.30 (m [dm centered at $3.38 \mathrm{ppm}, J=13.0 \mathrm{~Hz}], 2 \mathrm{H}), 3.18-2.98$ (very broad q centered at $3.08 \mathrm{ppm}, J \approx 11.5 \mathrm{~Hz}, 2 \mathrm{H}), 2.33-2.10(\mathrm{~m}, 4 \mathrm{H}) .{ }^{13} \mathrm{C} \mathrm{NMR}\left(100 \mathrm{MHz}, \mathrm{DMSO}-\mathrm{d}_{6}\right)$ : $\delta$ 145.38, 138.85, 131.16 (2C), 130.74 (2C), 121.11, 119.20, 54.04, 41.85 (2C), 30.43, 28.42 (2C). HRMS (ESI, $\mathrm{CH}_{2} \mathrm{Cl}_{2} / \mathrm{MeOH}$ : 90/10) Exact mass calculated for $\mathrm{C}_{14} \mathrm{H}_{18} \mathrm{~N}_{4}{ }^{79} \mathrm{Br}[\mathrm{M}+\mathrm{H}]^{+}$: 321.07093, found: 321.0709.

4-(4-(4-Methoxybenzyl)-1H-1,2,3-triazol-1-yl)piperidine hydrochloride (4c): ${ }^{1} \mathrm{H}$ NMR (400 MHz, DMSO-d ${ }_{6}$ ): $\delta$ 9.36-9.15 (broad envelope which topped at 9.25 and $9.23 \mathrm{ppm}, 1 \mathrm{H}$ ), 9.15-8.90 (broad envelope which topped at 9.05 and 9.03 ppm, 1H), 7.89 (s, 1H), 7.18 (half part of an $\mathrm{A}_{2} \mathrm{X}_{2}$ system, 2H), 6.86 (half part of an $\mathrm{A}_{2} \mathrm{X}_{2}$ system, $2 \mathrm{H}$ ), 4.77 (tt, $J=10.7,4.4 \mathrm{~Hz}$, $1 \mathrm{H}), 3.92(\mathrm{~s}, 2 \mathrm{H}), 3.71(\mathrm{~s}, 3 \mathrm{H}), 3.43-3.32$ (m [dm centered at $3.375 \mathrm{ppm}, J=12.8 \mathrm{~Hz}$, $2 \mathrm{H})$, 3.15-3.01 (very broad q centered at $3.08 \mathrm{ppm}, J \approx 11.5 \mathrm{~Hz}, 2 \mathrm{H}), 2.32-2.12(\mathrm{~m}, 4 \mathrm{H}) .{ }^{13} \mathrm{C} \mathrm{NMR}$ (75 MHz, DMSO-d ${ }_{6}$ ): $\delta$ 157.59, 146.42 (broad and small), 131.28, 129.42 (2C), 120.89, 113.73 (2C), 54.92, 54.03, 41.80 (2C), 30.24, 28.41 (2C). HRMS (ESI, MeOH) Exact mass calculated for $\mathrm{C}_{15} \mathrm{H}_{21} \mathrm{~N}_{4} \mathrm{O}[\mathrm{M}+\mathrm{H}]^{+}: 273.17099$, found: 273.1708 .

4-(4-(4-Iodobenzyl)-1H-1,2,3-triazol-1-yl)piperidine (4d): ${ }^{1} \mathrm{H}$ NMR (300 $\left.\mathrm{MHz}, \mathrm{CDCl}_{3}\right): \delta$ 7.62 (half part of an $\mathrm{A}_{2} \mathrm{X}_{2}$ system, $2 \mathrm{H}$ ), 7.18 (broad s [ $\mathrm{t}$ after improving the resolution, $J=0.7$ $\mathrm{Hz}], 1 \mathrm{H}$ ), 7.02 (half part of an $\mathrm{A}_{2} \mathrm{X}_{2}$ system coupled with one $\mathrm{CH}_{2}, J=0.6 \mathrm{~Hz}, 2 \mathrm{H}$ ), 4.50 (tt, $J$ $=11.7,4.1 \mathrm{~Hz}, 1 \mathrm{H}), 4.02(\mathrm{~s}$ [td after improving the resolution, $J=0.8,0.6 \mathrm{~Hz}$ ], 2H), 3.32-3.16 (very broad d centered at $3.23 \mathrm{ppm}, J=12.7 \mathrm{~Hz}, 2 \mathrm{H}$ ), 2.77 (broad t, $J \approx 11.8 \mathrm{~Hz}, 2 \mathrm{H}$ ), 2.23$2.07(\mathrm{~m}, 2 \mathrm{H}), 1.87$ (qd, $J \approx 12.2,4.0 \mathrm{~Hz}, 2 \mathrm{H}$, partly superimposed with the signal of water). ${ }^{13} \mathrm{C}$ NMR (75 MHz, $\left.\mathrm{CDCl}_{3}\right): \delta$ 146.68, 138.80, 137.67 (2C), 130.82 (2C), 118.94, 91.75, 58.44, 45.40 (broad, 2C), 33.83 (broad, 2C), 31.86. HRMS (ESI, $\mathrm{CH}_{2} \mathrm{Cl}_{2} / \mathrm{MeOH}$ : 90/10) Exact mass calculated for $\mathrm{C}_{14} \mathrm{H}_{18} \mathrm{~N}_{4} \mathrm{I}[\mathrm{M}+\mathrm{H}]^{+}: 369.05707$, found: 369.0577 .

General procedure for preparation of compounds 6-20 and 24-26, 28: To a stirred solution of compound $4 \mathbf{a}$ (78 mg, $0.28 \mathrm{mmol}, 1.0$ equiv) in dichloromethane (10 mL) was added triethylamine $(0.11 \mathrm{~mL}, 0.78 \mathrm{mmol}, 2.75$ equiv) at room temperature under nitrogen atmosphere. After stirring for 15-20 min, 4-nitrobenzyl bromide 5a (73 mg, $0.335 \mathrm{mmol}, 1.2$ 
equiv) was then slowly added and the resulting mixture was refluxed (heating by an oil bath at $50{ }^{\circ} \mathrm{C}$ ) overnight. After completion of the reaction (monitored by TLC), the reaction mass was cooled and partitioned with $\mathrm{CH}_{2} \mathrm{Cl}_{2}$ / water. Organic layers were separated, washed with water, brine and dried over $\mathrm{Na}_{2} \mathrm{SO}_{4}$. The solvent was evaporated under reduced pressure and the residue was purified by column chromatography (basic alumina, 15-20\% ethyl acetate in hexanes as eluent) to get compound $\mathbf{1 5}$ as an off-white solid (53 $\mathrm{mg}, \mathbf{5 0 \%}$ ).

General procedure for the reduction of nitro compounds 10, 15, 20 to amines 21, 22, 23: To a stirred solution of nitro compound 10 (150 mg, $0.395 \mathrm{mmol}, 1.0$ equiv) in ethanol/water (3:1) (4 mL) was added Fe powder (155 mg, $2.765 \mathrm{mmol}, 7.0$ equiv) and ammonium chloride (150 mg, $2.80 \mathrm{mmol}, 7.1$ equiv) at room temperature under nitrogen. The reaction mass was heated to $50{ }^{\circ} \mathrm{C}$ and then maintained for $1 \mathrm{~h}$ at $50^{\circ} \mathrm{C}$. After completion of the reaction (monitored by TLC, mobile phase: $50 \%$ EtOAc in hexane; $\mathrm{R}_{f}$ : reaction product: 0.5 , starting material: 0.55, [UV active]), the reaction mixture was filtered through a pad of celite which was washed with ethanol $(3 \times 20 \mathrm{~mL})$. The filtrate was evaporated under reduced pressure and extracted with ethyl acetate. Combined organic layers were dried over $\mathrm{Na}_{2} \mathrm{SO}_{4}$. The solvent were evaporated under reduced pressure and purification by column chromatography (basic alumina, 2\% methanol in $\mathrm{CH}_{2} \mathrm{Cl}_{2}$ as eluent) afforded the amine 21 as an off-white solid (90 $\mathrm{mg}, 65 \%)$.

Similarly $\mathbf{1 5}$ and $\mathbf{2 0}$ were reduced to $\mathbf{2 2}$ and $\mathbf{2 3}$ in 62 and 58\% yield respectively.

Preparation of 4-((4-(4-(4-bromobenzyl)-1H-1,2,3-triazol-1-yl)piperidin-1yl)methyl)benzoic acid, compound 27: To a stirred solution of ester 26 (100 mg, 0.213 mmol, 1.0 equiv) in methanol $(5 \mathrm{~mL})$ was added $2 \mathrm{~N}$ aqueous sodium hydroxide $(5 \mathrm{~mL})$ at room temperature under nitrogen atmosphere. The resulting mixture was stirred for $16 \mathrm{~h}$. After completion of the reaction, the $\mathrm{pH}$ was adjusted to neutral with $2 \mathrm{~N} \mathrm{HCl}$ and the resulting mixture was extracted with ethyl acetate $(2 \times 20 \mathrm{~mL})$. The combined organic layers were washed with water, brine and dried over $\mathrm{Na}_{2} \mathrm{SO}_{4}$. Evaporation under reduced pressure and purification by column chromatography (60-120 silica gel, 1-2\% methanol in dichloromethane as eluent) afforded carboxylic acid 27 as an off-white solid (77 $\mathrm{mg}, 79 \%$ ).

Preparation of 4-(4-(4-ethynylbenzyl)-1H-1,2,3-triazol-1-yl)-1-(4-nitrobenzyl)piperidine, compound 29: To a stirred solution of iodide 28 (150 mg, $0.29 \mathrm{mmol}, 1.0$ equiv) in dimethylformamide DMF (4 mL) was added $\mathrm{Pd}\left(\mathrm{PPh}_{3}\right)_{2} \mathrm{Cl}_{2}$ (18 mg, $0.026 \mathrm{mmol}, 0.09$ equiv), $\mathrm{CuI}$ (11 mg, $0.058 \mathrm{mmol}, 0.2$ equiv) and triethylamine $(0.5 \mathrm{~mL}, 3.55 \mathrm{mmol}, 12$ equiv) at room 
temperature under nitrogen atmosphere. The reaction mixture was degassed for 15-20 min and (trimethylsilyl)acetylene $(0.08 \mathrm{~mL}, 0.58 \mathrm{mmol}, 2.0$ equiv) was slowly added at room temperature. The resulting mixture was stirred for 4-5 h. After completion of the reaction, it was filtered through celite which was washed with ethyl acetate. Filtrate was evaporated under reduced pressure, diluted with chilled water and extracted with ethyl acetate. Organic layers were washed with water, brine and dried over $\mathrm{Na}_{2} \mathrm{SO}_{4}$. The solvent was evaporated under reduced pressure. The obtained crude product (130 mg) was dissolved in methanol (2 $\mathrm{mL}$ ) and potassium carbonate (102 $\mathrm{mg}, 0.74 \mathrm{mmol}, 2.5$ equiv) was added. After stirring for 30 min at room temperature, the reaction was monitored by TLC. When it was complete, the reaction mixture was extracted with ethyl acetate. The combined organic layers were washed with water, brine and dried over $\mathrm{Na}_{2} \mathrm{SO}_{4}$. Evaporation under reduced pressure and purification by column chromatography (basic alumina, 15-20\% ethyl acetate in hexanes as eluent) afforded alkyne 29 as an off-white solid (75 $\mathrm{mg}, 63 \%)$.

(6): ${ }^{1} \mathrm{H}$ NMR (400 MHz, $\left.\mathrm{CDCl}_{3}\right): \delta 7.35-7.20(\mathrm{~m}, 10 \mathrm{H}), 7.16($ broad s, $1 \mathrm{H}), 4.43(\mathrm{tt}, J=11.5$, $4.3 \mathrm{~Hz}, 1 \mathrm{H}), 4.08(\mathrm{~s}, 2 \mathrm{H}), 3.54(\mathrm{~s}, 2 \mathrm{H}), 3.04-2.95$ (m [dm centered at $2.99 \mathrm{ppm}, J=12.0 \mathrm{~Hz}$ ], 2H), 2.24-2.07 (m, 4H), 2.07-1.94 (m, 2H). $\left.{ }^{13} \mathrm{C} \mathrm{NMR} \mathrm{(100} \mathrm{MHz,} \mathrm{CDCl}_{3}\right): \delta 147.48,139.15$, 138.11 (broad and small), 129.02 (2C), 128.77 (2C), 128.62 (2C), 128.33 (2C), 127.22, 126.48, 118.94, 62.74, 58.23, 52.22 (2C), 32.71 (broad, 2C), 32.41. HRMS (ESI, $\mathrm{MeOH} / \mathrm{CH}_{2} \mathrm{Cl}_{2}$ : 90/10) Exact mass calculated for $\mathrm{C}_{21} \mathrm{H}_{25} \mathrm{~N}_{4}[\mathrm{M}+\mathrm{H}]^{+}$: 333.20737, found: 333.2077; exact mass calculated for $\mathrm{C}_{21} \mathrm{H}_{24} \mathrm{~N}_{4} \mathrm{Na}[\mathrm{M}+\mathrm{Na}]^{+}$: 355.18932, found: 355.1894 . M.P.: $110.0-112.0^{\circ} \mathrm{C}$.

(7): ${ }^{1} \mathrm{H}$ NMR (400 MHz, $\mathrm{CDCl}_{3}$ ): $\delta 7.44$ (half part of an $\mathrm{A}_{2} \mathrm{X}_{2}$ system, 2H), 7.33-7.28 (m, $\left.\mathrm{H}_{\text {meta }}, 2 \mathrm{H}\right), 7.27-7.22(\mathrm{~m}, 5 \mathrm{H}), 7.19$ (very broad d, $\left.J=8.2 \mathrm{~Hz}, 2 \mathrm{H}\right), 7.16$ (broad s, $\left.1 \mathrm{H}\right), 4.42$ (tt, $J=11.5,4.3 \mathrm{~Hz}, 1 \mathrm{H}), 4.08(\mathrm{~s}, 2 \mathrm{H}), 3.48(\mathrm{~s}, 2 \mathrm{H}), 3.01-2.91$ (m [dm centered at $2.96 \mathrm{ppm}, J$ $=11.9 \mathrm{~Hz}], 2 \mathrm{H}), 2.23-2.07(\mathrm{~m}, 4 \mathrm{H}), 2.00(\mathrm{qd}, J=12.1,3.6 \mathrm{~Hz}, 2 \mathrm{H}) .{ }^{13} \mathrm{C} \mathrm{NMR}(75 \mathrm{MHz}$, $\mathrm{CDCl}_{3}$ ): $\delta 147.51,139.11,137.23$ (broad and small), 131.45 (2C), 130.59 (2C), 128.76 (2C), 128.63 (2C), 126.49, 121.02 (small), 118.97, 61.97, 58.10 (broad), 52.18 (2C), 32.63 (broad, 2C), 32.40. HRMS (ESI, MeOH / $\mathrm{CH}_{2} \mathrm{Cl}_{2}$ : 90/10) Exact mass calculated for $\mathrm{C}_{21} \mathrm{H}_{23} \mathrm{~N}_{4}{ }^{79} \mathrm{BrNa}$ $[\mathrm{M}+\mathrm{Na}]^{+}$: 433.09983, found: 433.1001; exact mass calculated for $\mathrm{C}_{21} \mathrm{H}_{24} \mathrm{~N}_{4}{ }^{79} \mathrm{Br}[\mathrm{M}+\mathrm{H}]^{+}$: 411.11788, found: 411.1181; exact mass calculated for $\mathrm{C}_{21} \mathrm{H}_{23} \mathrm{~N}_{4}{ }^{79} \mathrm{BrK}[\mathrm{M}+\mathrm{K}]^{+}: 449.07377$, found: 449.0739 . M.P: $108.5-109.8^{\circ} \mathrm{C}$. 
(8): ${ }^{1} \mathrm{H}$ NMR (400 MHz, $\mathrm{CDCl}_{3}$ ): $\delta$ 7.33-7.27 (m, $\left.\mathrm{H}_{\text {meta }}, 2 \mathrm{H}\right), 7.27-7.19$ (m, 5H), 7.15 (broad s, 1H), 6.85 (half part of an $\mathrm{A}_{2} \mathrm{X}_{2}$ system, 2H), 4.42 (tt, $\left.J=11.6,4.2 \mathrm{~Hz}, 1 \mathrm{H}\right), 4.07$ (s, 2H), $3.80(\mathrm{~s}, 3 \mathrm{H}), 3.47(\mathrm{~s}, 2 \mathrm{H}), 3.02-2.93(\mathrm{~m}[\mathrm{dm}$ centered at $2.98 \mathrm{ppm}, J=11.8 \mathrm{~Hz}], 2 \mathrm{H}), 2.17-$ $2.07(\mathrm{~m}, 4 \mathrm{H}), 1.98$ (qd, $J=12.1,3.5 \mathrm{~Hz}, 2 \mathrm{H}) .{ }^{13} \mathrm{C} \mathrm{NMR}\left(75 \mathrm{MHz}, \mathrm{CDCl}_{3}\right): \delta$ 158.85, 147.46, $139.15,130.19$ (2C), 130.12, 128.76 (2C), 128.62 (2C), 126.48, 118.92, 113.69 (2C), 62.13, 58.29, 55.27, 52.10 (2C), 32.72 (2C), 32.40. HRMS (ESI, $\mathrm{MeOH} / \mathrm{CH}_{2} \mathrm{Cl}_{2}$ : 90/10) Exact mass calculated for $\mathrm{C}_{22} \mathrm{H}_{26} \mathrm{~N}_{4} \mathrm{ONa}[\mathrm{M}+\mathrm{Na}]^{+}$: 385.19988, found: 385.2001 , exact mass calculated for $\mathrm{C}_{22} \mathrm{H}_{26} \mathrm{~N}_{4} \mathrm{OK}[\mathrm{M}+\mathrm{K}]^{+}$: 401.17382, found: 401.1735. M.P: $122.0-123.6{ }^{\circ} \mathrm{C}$.

(9): ${ }^{1} \mathrm{H}$ NMR $\left(300 \mathrm{MHz}, \mathrm{CDCl}_{3}\right): \delta 7.34-7.19(\mathrm{~m}, 7 \mathrm{H}), 7.16$ (broad s [t after improving the resolution, $J=0.8 \mathrm{~Hz}$ ], $1 \mathrm{H}$ ), 7.00 (half part of an $\mathrm{A}_{2} \mathrm{X}_{2}$ system coupled with F with $J_{\mathrm{HF}} \approx 8.8$ $\mathrm{Hz}, 2 \mathrm{H}), 4.43$ (tt, $J=11.3,4.4 \mathrm{~Hz}, 1 \mathrm{H}), 4.08$ (s, 2H), 3.49 (s, 2H), 3.04-2.89 (m [dm centered at $2.97 \mathrm{ppm}, J=11.5 \mathrm{~Hz}$ ], 2H), 2.24-2.07 (m, 4H), 2.07-1.91 (m [almost qd centered at 1.99 $\mathrm{ppm}, J \approx 12,3.3 \mathrm{~Hz}], 2 \mathrm{H}) .{ }^{13} \mathrm{C} \mathrm{NMR}\left(100 \mathrm{MHz}, \mathrm{CDCl}_{3}\right): \delta 162.11\left(\mathrm{~d}, J_{\mathrm{CF}}=245.1 \mathrm{~Hz}\right)$, 147.51, 139.16, 133.90 (broad and small), 130.42 (d, $\left.J_{\mathrm{CF}}=7.9 \mathrm{~Hz}, 2 \mathrm{C}\right), 128.77(2 \mathrm{C}), 128.63$ (2C), 126.49, 118.95, $115.13\left(\mathrm{~d}, J_{\mathrm{CF}}=21.2 \mathrm{~Hz}, 2 \mathrm{C}\right), 61.92,58.21,52.16$ (2C), 32.71 (broad, 2C), 32.48. ${ }^{19} \mathrm{~F}$ NMR (282 MHz, $\left.\mathrm{CDCl}_{3}\right): \delta-115.65$. HRMS (ESI, $\mathrm{MeOH} / \mathrm{CH}_{2} \mathrm{Cl}_{2}: 90 / 10$ ) Exact mass calculated for $\mathrm{C}_{21} \mathrm{H}_{24} \mathrm{~N}_{4} \mathrm{~F}[\mathrm{M}+\mathrm{H}]^{+}: 351.19795$, found: 351.1982 ; exact mass calculated for $\mathrm{C}_{21} \mathrm{H}_{23} \mathrm{~N}_{4} \mathrm{FNa}[\mathrm{M}+\mathrm{Na}]^{+}$: 373.17989, found: 373.1798. M.P.: 104.0-107.0 ${ }^{\circ} \mathrm{C}$.

(10): ${ }^{1} \mathrm{H}$ NMR (400 MHz, $\left.\mathrm{CDCl}_{3}\right): \delta 8.18$ (half part of an $\mathrm{A}_{2} \mathrm{X}_{2}$ system, $2 \mathrm{H}$ ), 7.51 (half part of an $\mathrm{A}_{2} \mathrm{X}_{2}$ system, 2H), 7.34-7.20 (m, 5H), 7.18 (broad s, $\left.1 \mathrm{H}\right), 4.44(\mathrm{tt}, J=11.4,4.4 \mathrm{~Hz}, 1 \mathrm{H})$, $4.08(\mathrm{~s}, 2 \mathrm{H}), 3.63(\mathrm{~s}, 2 \mathrm{H}), 3.04-2.89(\mathrm{~m}[\mathrm{dm}$ centered at $2.96 \mathrm{ppm}, J=11.7 \mathrm{~Hz}], 2 \mathrm{H}), 2.24$ (broad t, $J=11.3 \mathrm{~Hz}, 2 \mathrm{H}), 2.19-2.11(\mathrm{~m}, 2 \mathrm{H}), 2.11-1.98$ (m [almost qd centered at $2.05 \mathrm{ppm}$, $J \approx 12,3.5 \mathrm{~Hz}], 2 \mathrm{H}) \cdot{ }^{13} \mathrm{C}$ NMR $\left(75 \mathrm{MHz}, \mathrm{CDCl}_{3}\right): \delta 147.55,147.31,146.19$ (broad and small), 139.10, 129.33 (2C), 128.77 (2C), 128.64 (2C), 126.51, 123.63 (2C), 119.06, 61.81, 57.91 (broad), 52.33 (2C), 32.58 (broad, 2C), 32.40. HRMS (ESI, MeOH / $\mathrm{CH}_{2} \mathrm{Cl}_{2}$ : 90/10) Exact mass calculated for $\mathrm{C}_{21} \mathrm{H}_{23} \mathrm{~N}_{5} \mathrm{O}_{2} \mathrm{Na}[\mathrm{M}+\mathrm{Na}]^{+}: 400.17439$, found: 400.1747, Exact mass calculated for $\mathrm{C}_{21} \mathrm{H}_{24} \mathrm{~N}_{5} \mathrm{O}_{2}[\mathrm{M}+\mathrm{H}]^{+}$: 378.19245, found: 378.1928; Exact mass calculated for $\mathrm{C}_{21} \mathrm{H}_{23} \mathrm{~N}_{5} \mathrm{O}_{2} \mathrm{~K}[\mathrm{M}+\mathrm{K}]^{+}$: 416.14833, found: 416.1486. M.P.: 88.0-92.5 ${ }^{\circ} \mathrm{C}$.

(11): ${ }^{1} \mathrm{H}$ NMR (400 MHz, $\left.\mathrm{CDCl}_{3}\right): \delta 7.41$ (half part of an $\mathrm{A}_{2} \mathrm{X}_{2}$ system, 2H), 7.36-7.29 (m, $4 \mathrm{H}), 7.29-7.23(\mathrm{~m}, 1 \mathrm{H}), 7.18$ (broad s, 1H), 7.13 (half part of an $\mathrm{A}_{2} \mathrm{X}_{2}$ system, 2H), 4.43 (tt, $J$ $=11.5,4.3 \mathrm{~Hz}, 1 \mathrm{H}), 4.02(\mathrm{~s}, 2 \mathrm{H}), 3.54(\mathrm{~s}, 2 \mathrm{H}), 3.04-2.96(\mathrm{~m}[\mathrm{dm}$ centered at $3.00 \mathrm{ppm}, J=$ $12.1 \mathrm{~Hz}], 2 \mathrm{H}), 2.22-2.08(\mathrm{~m}, 4 \mathrm{H}), 2.08-1.95(\mathrm{~m}, 2 \mathrm{H}) .{ }^{13} \mathrm{C} \mathrm{NMR}\left(75 \mathrm{MHz}, \mathrm{CDCl}_{3}\right): \delta 146.75$, 
138.10, 138.01, 131.68 (2C), 130.49 (2C), 129.01 (2C), 128.32 (2C), 127.23, 120.37, 118.93, 62.71, 58.27, 52.17 (2C), 32.67 (2C), 31.76. HRMS (ESI, $\mathrm{MeOH} / \mathrm{CH}_{2} \mathrm{Cl}_{2}: 90 / 10$ ) Exact mass calculated for $\mathbf{C}_{\mathbf{2 1}} \mathbf{H}_{\mathbf{2 4}} \mathbf{N}_{\mathbf{4}}{ }^{79} \mathrm{Br}[\mathrm{M}+\mathrm{H}]^{+}$: 411.11788, found: 411.1182; exact mass calculated for $\mathrm{C}_{21} \mathrm{H}_{23} \mathrm{~N}_{4}{ }^{79} \mathrm{BrNa}[\mathrm{M}+\mathrm{Na}]^{+}$: 433.09983 , found: 433.1002 . M.P.: $118.0-123.0{ }^{\circ} \mathrm{C}$. (12): ${ }^{1} \mathrm{H}$ NMR $\left(400 \mathrm{MHz}, \mathrm{CDCl}_{3}\right): \delta 7.46-7.39$ (two half parts of $\mathrm{A}_{2} \mathrm{X}_{2}$ systems at 7.44 and $7.42 \mathrm{ppm}, 4 \mathrm{H}$ ), 7.20 (half part of an $\mathrm{A}_{2} \mathrm{X}_{2}$ system, 2H), 7.17 (broad s, $1 \mathrm{H}$ ), 7.14 (half part of an $\mathrm{A}_{2} \mathrm{X}_{2}$ system, 2H), $4.42(\mathrm{tt}, J=11.6,4.3 \mathrm{~Hz}, 1 \mathrm{H}), 4.03(\mathrm{~s}, 2 \mathrm{H}), 3.48(\mathrm{~s}, 2 \mathrm{H}), 3.01-2.92(\mathrm{~m}$ [dm centered at $2.96 \mathrm{ppm}, J=12.1 \mathrm{~Hz}$ ], 2H), 2.22-2.08 (m, 4H), 2.07-1.94 (m, 2H). ${ }^{13} \mathrm{C} \mathrm{NMR}$ (75 MHz, $\mathrm{CDCl}_{3}$ ): $\delta$ 146.80, 138.09, 137.25, 131.70 (2C), 131.44 (2C), 130.57 (2C), 130.50 (2C), 121.00, 120.39, 118.94, 61.96, 58.20, 52.16 (2C), 32.66 (2C), 31.77. HRMS (ESI, $\mathrm{MeOH} / \mathrm{CH}_{2} \mathrm{Cl}_{2}$ : 80/20) Exact mass calculated for $\mathrm{C}_{21} \mathrm{H}_{22} \mathrm{~N}_{4}{ }^{79} \mathrm{Br}_{2} \mathrm{Na}[\mathrm{M}+\mathrm{Na}]^{+}:$511.01034, found: 511.0106. M.P.: $148.0-150.0{ }^{\circ} \mathrm{C}$.

(13): ${ }^{1} \mathrm{H}$ NMR (400 MHz, $\mathrm{CDCl}_{3}$ ): $\delta 7.42$ (half part of an $\mathrm{A}_{2} \mathrm{X}_{2}$ system, $2 \mathrm{H}$ ), 7.22 (slightly broadened half part of an $\mathrm{A}_{2} \mathrm{X}_{2}$ system, 2H), 7.17 (broad s, $1 \mathrm{H}$ ), 7.13 (half part of an $\mathrm{A}_{2} \mathrm{X}_{2}$ system, 2H), 6.86 (half part of an $\mathrm{A}_{2} \mathrm{X}_{2}$ system, 2H), 4.42 (tt, $\left.J=11.7,4.3 \mathrm{~Hz}, 1 \mathrm{H}\right), 4.02$ (s, $2 \mathrm{H}), 3.80(\mathrm{~s}, 3 \mathrm{H}), 3.48(\mathrm{~s}, 2 \mathrm{H}), 3.04-2.94(\mathrm{~m}$ [dm centered at $2.99 \mathrm{ppm}, J=11.9 \mathrm{~Hz}$ ], 2H), 2.18-2.07 (m, 4H), $1.99(\mathrm{qd}, J=12.0,3.4 \mathrm{~Hz}, 2 \mathrm{H}) .{ }^{13} \mathrm{CNMR}\left(75 \mathrm{MHz}, \mathrm{CDCl}_{3}\right): \delta 158.82$, 146.74, 138.11, 131.68 (2C), 130.49 (2C), 130.20 (2C), 120.37, 118.89, 113.67 (2C), 62.10, 58.33, 55.27, 52.06 (2C), 32.70 (2C), 31.77. HRMS (ESI, $\mathrm{MeOH} / \mathrm{CH}_{2} \mathrm{Cl}_{2}$ : 90/10) Exact mass calculated for $\mathrm{C}_{22} \mathrm{H}_{26} \mathrm{~N}_{4} \mathrm{O}^{79} \mathrm{Br}[\mathrm{M}+\mathrm{H}]^{+}$: 441.12845, found: 441.1287; exact mass calculated for $\mathrm{C}_{22} \mathrm{H}_{25} \mathrm{~N}_{4} \mathrm{O}^{79} \mathrm{BrNa}[\mathrm{M}+\mathrm{Na}]^{+}$: 463.11039, found: 463.1100. M.P.: 130.5$132.0^{\circ} \mathrm{C}$.

(14): ${ }^{1} \mathrm{H}$ NMR $\left(400 \mathrm{MHz}, \mathrm{CDCl}_{3}\right.$ ): $\delta 7.42$ (half part of an $\mathrm{A}_{2} \mathrm{X}_{2}$ system, 2H), 7.35-7.22 (broad $\mathrm{m}, 2 \mathrm{H}$ ), 7.17 (broad s, 1H), 7.13 (half part of an $\mathrm{A}_{2} \mathrm{X}_{2}$ system, $2 \mathrm{H}$ ), 7.01 (half part of an $\mathrm{A}_{2} \mathrm{X}_{2}$ system coupled with F with $\left.J_{\mathrm{HF}}=9.0 \mathrm{~Hz}, 2 \mathrm{H}\right), 4.44(\mathrm{tt}, J=11.4,4.2 \mathrm{~Hz}, 1 \mathrm{H}), 4.02(\mathrm{~s}, 2 \mathrm{H})$, 3.51 (broad s, 2H), 3.07-2.89 (m [dm centered at $2.98 \mathrm{ppm}, J=11.0 \mathrm{~Hz}], 2 \mathrm{H}), 2.26-2.09$ (braod m, 4H), 2.09-1.94 (m, 2H). ${ }^{13} \mathrm{C}$ NMR (100 MHz, $\left.\mathrm{CDCl}_{3}\right): \delta 162.13\left(\mathrm{~d}, J_{\mathrm{CF}}=245.4\right.$ $\mathrm{Hz}$ ), 146.80, 138.10, 133.73 (broad), 131.71 (2C), 130.50 (2C), 130.43 (broad, 2C), 120.40, $118.95\left(\right.$ broad d, $\left.J_{\mathrm{CF}}=2.1 \mathrm{~Hz}\right), 115.18\left(\mathrm{~d}, J_{\mathrm{CF}}=21.2 \mathrm{~Hz}, 2 \mathrm{C}\right), 61.85,58.20$ (broad), 52.08 (2C), 32.62 (broad), 31.78. ${ }^{19} \mathrm{~F}$ NMR (376 $\mathrm{MHz}, \mathrm{CDCl}_{3}$ ): $\delta$-115.56. HRMS (ESI, $\mathrm{MeOH} / \mathrm{CH}_{2} \mathrm{Cl}_{2}$ : 90/10) Exact mass calculated for $\mathrm{C}_{21} \mathrm{H}_{23} \mathrm{~N}_{4} \mathrm{~F}^{79} \mathrm{Br}[\mathrm{M}+\mathrm{H}]^{+}:$429.10846, 
found: 429.1088; exact mass calculated for $\mathrm{C}_{21} \mathrm{H}_{22} \mathrm{~N}_{4} \mathrm{~F}^{79} \mathrm{BrNa}[\mathrm{M}+\mathrm{Na}]^{+}$: 451.09041 , found: 451.0905. M.P.: $136.5-140.0^{\circ} \mathrm{C}$.

(15): ${ }^{1} \mathrm{H}$ NMR (400 MHz, $\left.\mathrm{CDCl}_{3}\right): \delta 8.18$ (half part of an $\mathrm{A}_{2} \mathrm{X}_{2}$ system, $2 \mathrm{H}$ ), 7.51 (half part of an $\mathrm{A}_{2} \mathrm{X}_{2}$ system coupled with one $\mathrm{CH}_{2}, J=0.7 \mathrm{~Hz}, 2 \mathrm{H}$ ), 7.42 (half part of an $\mathrm{A}_{2} \mathrm{X}_{2}$ system, 2H), 7.19 (broad s [t after improving the resolution, $J=0.7 \mathrm{~Hz}$ ] $1 \mathrm{H}$ ), 7.14 (half part of an $\mathrm{A}_{2} \mathrm{X}_{2}$ system system coupled with one $\left.\mathrm{CH}_{2}, J=0.7 \mathrm{~Hz}, 2 \mathrm{H}\right), 4.44(\mathrm{tt}, J=11.5,4.4 \mathrm{~Hz}, 1 \mathrm{H})$, $4.03(\mathrm{~s}, 2 \mathrm{H}), 3.63(\mathrm{~s}, 2 \mathrm{H}), 3.02-2.91(\mathrm{~m}[\mathrm{dm}$ centered at $2.96 \mathrm{ppm}, J=12.1 \mathrm{~Hz}], 2 \mathrm{H}), 2.30-$ $2.20(\mathrm{~m}, 2 \mathrm{H}), 2.20-2.12(\mathrm{~m}, 2 \mathrm{H}), 2.11-1.99(\mathrm{~m}, 2 \mathrm{H}) .{ }^{13} \mathrm{C} \mathrm{NMR}\left(75 \mathrm{MHz}, \mathrm{CDCl}_{3}\right): \delta$ 147.30, 146.84, 146.19, 138.07, 131.71 (2C), 130.50 (2C), 129.31 (2C), 123.63 (2C), 120.41, 119.03, 61.81, 58.01, 52.33 (2C), 32.61 (2C), 31.78. HRMS (ESI, $\mathrm{MeOH} / \mathrm{CH}_{2} \mathrm{Cl}_{2}: 90 / 10$ ) Exact mass calculated for $\mathrm{C}_{21} \mathrm{H}_{22} \mathrm{~N}_{5} \mathrm{O}_{2}{ }^{79} \mathrm{BrNa}[\mathrm{M}+\mathrm{Na}]^{+}$: 478.08491, found: 478.0855. M.P.: 119.5$122.4^{\circ} \mathrm{C}$.

(16): ${ }^{1} \mathrm{H}$ NMR $\left(400 \mathrm{MHz}, \mathrm{CDCl}_{3}\right): \delta 7.35-7.29(\mathrm{~m}, 4 \mathrm{H}), 7.29-7.23(\mathrm{~m}, 1 \mathrm{H}), 7.17$ (half part of an $\mathrm{A}_{2} \mathrm{X}_{2}$ system, 2H), 7.14 (broad s, 1H), 6.84 (half part of an $\mathrm{A}_{2} \mathrm{X}_{2}$ system, 2H), 4.42 (tt, $J=$ 11.5, $4.3 \mathrm{~Hz}, 1 \mathrm{H}), 4.01(\mathrm{~s}, 2 \mathrm{H}), 3.79(\mathrm{~s}, 3 \mathrm{H}), 3.54(\mathrm{~s}, 2 \mathrm{H}), 3.05-2.94$ (m [dm centered at 2.99 ppm, $J=12.0 \mathrm{~Hz}], 2 \mathrm{H}), 2.23-2.08(\mathrm{~m}, 4 \mathrm{H}), 2.07-1.95(\mathrm{~m}, 2 \mathrm{H}) .{ }^{13} \mathrm{C} \mathrm{NMR}\left(75 \mathrm{MHz}, \mathrm{CDCl}_{3}\right): \delta$ 158.23, 147.99, 138.03, 131.19, 129.72 (2C), 129.04 (2C), 128.32 (2C), 127.22, 118.84, 114.02 (2C), 62.73, 58.19, 55.28, 52.20 (2C), 32.67 (2C), 31.49. HRMS (ESI, $\mathrm{MeOH} / \mathrm{CH}_{2} \mathrm{Cl}_{2}$ : 90/10) Exact mass calculated for $\mathrm{C}_{22} \mathrm{H}_{27} \mathrm{~N}_{4} \mathrm{O}[\mathrm{M}+\mathrm{H}]^{+}$: 363.21794, found: 363.2182; exact mass calculated for $\mathrm{C}_{22} \mathrm{H}_{26} \mathrm{~N}_{4} \mathrm{ONa}[\mathrm{M}+\mathrm{Na}]^{+}$: 385.19988 , found: 385.2001 ; exact mass calculated for $\mathrm{C}_{22} \mathrm{H}_{26} \mathrm{~N}_{4} \mathrm{OK}[\mathrm{M}+\mathrm{K}]^{+}$: 401.17382, found: 401.1737. M.P.: 106.5$109.0^{\circ} \mathrm{C}$.

(17): ${ }^{1} \mathrm{H}$ NMR (400 MHz, $\mathrm{CDCl}_{3}$ ): $\delta 7.44$ (half part of an $\mathrm{A}_{2} \mathrm{X}_{2}$ system, $2 \mathrm{H}$ ), 7.22-7.15 (two half parts of $\mathrm{A}_{2} \mathrm{X}_{2}$ systems at 7.19 and $\left.7.17 \mathrm{ppm}, 4 \mathrm{H}\right), 7.14$ (broad s, 1H), 6.84 (half part of an $\mathrm{A}_{2} \mathrm{X}_{2}$ system, 2H), 4.41 (tt, $\left.J=11.6,4.3 \mathrm{~Hz}, 1 \mathrm{H}\right), 4.02$ (s, 2H), 3.79 (s, 3H), 3.48 (s, 2H), 3.00-2.91 (m [dm centered at 2.95 ppm, $J=12.0 \mathrm{~Hz}], 2 \mathrm{H}), 2.20-2.08(\mathrm{~m}, 4 \mathrm{H}), 2.06-1.93$ (m, $2 \mathrm{H}) .{ }^{13} \mathrm{C} \mathrm{NMR}\left(75 \mathrm{MHz}, \mathrm{CDCl}_{3}\right): \delta 158.25,148.02,137.26,131.44$ (2C), 131.19, 130.59 (2C), 129.73 (2C), 121.00, 118.87, 114.03 (2C), 61.97, 58.10, 55.28, 52.19 (2C), 32.65 (2C), 31.50. HRMS (ESI, $\mathrm{MeOH} / \mathrm{CH}_{2} \mathrm{Cl}_{2}$ : 90/10) Exact mass calculated for $\mathrm{C}_{22} \mathrm{H}_{25} \mathrm{~N}_{4} \mathrm{O}^{79} \mathrm{BrNa}$ $[\mathrm{M}+\mathrm{H}]^{+}: 463.11039$, found: 463.1100 . M.P.: $133.5-136.0^{\circ} \mathrm{C}$.

(18): ${ }^{1} \mathrm{H}$ NMR (400 MHz, $\mathrm{CDCl}_{3}$ ): $\delta 7.22$ (slightly broadened half part of an $\mathrm{A}_{2} \mathrm{X}_{2}$ system, 2H), 7.17 (half part of an $\mathrm{A}_{2} \mathrm{X}_{2}$ system, $2 \mathrm{H}$ ), 7.14 (broad s, 1H), 6.89-6.81 (two half parts of 
$\mathrm{A}_{2} \mathrm{X}_{2}$ systems at 6.86 and $\left.6.84 \mathrm{ppm}, 4 \mathrm{H}\right), 4.42(\mathrm{tt}, J=11.6,4.2 \mathrm{~Hz}, 1 \mathrm{H}), 4.01(\mathrm{~s}, 2 \mathrm{H}), 3.80$ (s, $3 \mathrm{H}), 3.79(\mathrm{~s}, 3 \mathrm{H}), 3.48(\mathrm{~s}, 2 \mathrm{H}), 3.05-2.92(\mathrm{~m}$ [dm centered at $2.98 \mathrm{ppm}, J=11.8 \mathrm{~Hz}$ ], 2H), 2.20-2.06 (m, 4H), 2.06-1.92 (m, 2H). $\left.{ }^{13} \mathrm{C} \mathrm{NMR} \mathrm{(100} \mathrm{MHz,} \mathrm{CDCl}_{3}\right): \delta$ 158.87, 158.27, 147.98, 131.25, 130.21 (2C), 129.73 (2C), 118.82, 114.05 (2C), 113.70 (2C), 62.11, 58.25, 55.29, 55.28, 52.09 (2C), 32.70, 31.51. HRMS (ESI, $\mathrm{MeOH} / \mathrm{CH}_{2} \mathrm{Cl}_{2}$ : 90/10) Exact mass calculated for $\mathrm{C}_{23} \mathrm{H}_{29} \mathrm{~N}_{4} \mathrm{O}_{2}[\mathrm{M}+\mathrm{H}]^{+}:$393.2285, found: 393.2289; exact mass calculated for $\mathrm{C}_{23} \mathrm{H}_{28} \mathrm{~N}_{4} \mathrm{O}_{2} \mathrm{Na}[\mathrm{M}+\mathrm{Na}]^{+}$: 415.21045 , found: 415.2106 . M.P.: $132.5-134.1^{\circ} \mathrm{C}$.

(19): ${ }^{1} \mathrm{H}$ NMR (400 MHz, $\mathrm{CDCl}_{3}$ ): $\delta 7.27$ (half part of an $\mathrm{A}_{2} \mathrm{X}_{2}$ system coupled with $\mathrm{F}, J_{\mathrm{HF}}=$ $5.5 \mathrm{~Hz}, 2 \mathrm{H}$ ), 7.17 (half part of an $\mathrm{A}_{2} \mathrm{X}_{2}$ system, 2H), 7.14 (broad s, 1H), 7.00 (half part of an $\mathrm{A}_{2} \mathrm{X}_{2}$ system coupled with $\mathrm{F}, J_{\mathrm{HF}}=8.8 \mathrm{~Hz}, 2 \mathrm{H}$ ), 6.84 (half part of an $\mathrm{A}_{2} \mathrm{X}_{2}$ system, 2H), 4.42 (tt, $J=11.6,4.3 \mathrm{~Hz}, 1 \mathrm{H}), 4.01(\mathrm{~s}, 2 \mathrm{H}), 3.79(\mathrm{~s}, 3 \mathrm{H}), 3.49$ (s, 2H), 3.00-2.93 (m [dm centered at $2.96 \mathrm{ppm}, J=12.1 \mathrm{~Hz}], 2 \mathrm{H}), 2.20-2.08(\mathrm{~m}, 4 \mathrm{H}), 2.06-1.93(\mathrm{~m}, 2 \mathrm{H}) .{ }^{13} \mathrm{C} \mathrm{NMR}(100 \mathrm{MHz}$, $\left.\mathrm{CDCl}_{3}\right): \delta 162.08\left(\mathrm{~d}, J_{\mathrm{CF}}=245.1 \mathrm{~Hz}\right), 158.27,148.01,133.86$ (broad), 131.22, $130.42\left(\mathrm{~d}, J_{\mathrm{CF}}\right.$ $=8.0 \mathrm{~Hz}, 2 \mathrm{C}), 129.73(2 \mathrm{C}), 118.86,115.12\left(\mathrm{~d}, J_{\mathrm{CF}}=21.2 \mathrm{~Hz}, 2 \mathrm{C}\right), 114.04(2 \mathrm{C}), 61.90,58.16$, 55.29, 52.14 (2C), 32.68 (2C), 31.51. ${ }^{19} \mathrm{~F}$ NMR (376 $\mathrm{MHz}, \mathrm{CDCl}_{3}$ ): $\delta$-115.63. HRMS (ESI, $\mathrm{MeOH} / \mathrm{CH}_{2} \mathrm{Cl}_{2}$ : 90/10) Exact mass calculated for $\mathrm{C}_{22} \mathrm{H}_{26} \mathrm{~N}_{4} \mathrm{OF}[\mathrm{M}+\mathrm{H}]^{+}: 381.20851$, found: 381.2086; exact mass calculated for $\mathrm{C}_{22} \mathrm{H}_{25} \mathrm{~N}_{4} \mathrm{OFNa}[\mathrm{M}+\mathrm{Na}]^{+}: 403.19046$, found: 403.1905; exact mass calculated for $\mathrm{C}_{22} \mathrm{H}_{25} \mathrm{~N}_{4} \mathrm{OFK}[\mathrm{M}+\mathrm{K}]^{+}:$419.1644, found: 419.1643. M.P.: 122.0$124.0^{\circ} \mathrm{C}$.

(20): ${ }^{1} \mathrm{H}$ NMR (400 MHz, $\left.\mathrm{CDCl}_{3}\right): \delta 8.18$ (half part of an $\mathrm{A}_{2} \mathrm{X}_{2}$ system, $2 \mathrm{H}$ ), 7.51 (half part of an $\mathrm{A}_{2} \mathrm{X}_{2}$ system, 2H), 7.18 (half part of an $\mathrm{A}_{2} \mathrm{X}_{2}$ system, 2H), 7.15 (broad s, 1H), 6.85 (half part of an $\mathrm{A}_{2} \mathrm{X}_{2}$ system, 2H), $4.43(\mathrm{tt}, J=11.5,4.4 \mathrm{~Hz}, 1 \mathrm{H}), 4.02(\mathrm{~s}, 2 \mathrm{H}), 3.79(\mathrm{~s}, 3 \mathrm{H}), 3.63$ (s, $2 \mathrm{H}), 3.00-2.91(\mathrm{~m}[\mathrm{dm}$ centered at $2.95 \mathrm{ppm}, J=12.0 \mathrm{~Hz}], 2 \mathrm{H}), 2.23(\mathrm{td}, J=11.8,2.1 \mathrm{~Hz}$, $2 \mathrm{H}), 2.18-2.11(\mathrm{~m}, 2 \mathrm{H}), 2.04(\mathrm{qd}, J=12.0,3.6 \mathrm{~Hz}, 2 \mathrm{H}) .{ }^{13} \mathrm{C} \mathrm{NMR}\left(75 \mathrm{MHz}, \mathrm{CDCl}_{3}\right): 158.26$, 148.10, 147.27, 146.23, 131.15, 129.74, 129.31, 123.64, 118.92, 114.03, 61.82, 57.91, 55.29, 52.36, 32.61, 31.50. HRMS (ESI, $\mathrm{MeOH} / \mathrm{CH}_{2} \mathrm{Cl}_{2}$ : 90/10) Exact mass calculated for $\mathrm{C}_{22} \mathrm{H}_{25} \mathrm{~N}_{5} \mathrm{O}_{3} \mathrm{Na}[\mathrm{M}+\mathrm{Na}]^{+}:$430.18496, found: 430.1853. M.P.: $124.9-127.5^{\circ} \mathrm{C}$.

(21): ${ }^{1} \mathrm{H}$ NMR (400 MHz, $\mathrm{CD}_{3} \mathrm{OD}$ ): $\delta 7.72$ (broad s [t after improving the resolution, $J=0.7$ $\mathrm{Hz}], 1 \mathrm{H}), 7.29-7.21(\mathrm{~m}, 4 \mathrm{H}), 7.18$ (ddt, $\left.J=7.6,6.1,1.7 \mathrm{~Hz}, \mathrm{H}_{\text {para }}, 1 \mathrm{H}\right), 7.08$ (half part of an $\mathrm{A}_{2} \mathrm{X}_{2}$ system, 2H), 6.70 (half part of an $\mathrm{A}_{2} \mathrm{X}_{2}$ system, 2H), 4.48 (tt, $J=10.8,4.8 \mathrm{~Hz}, 1 \mathrm{H}$ ), 4.02 (s, 2H), $3.54(\mathrm{~s}, 2 \mathrm{H}), 3.13-3.03(\mathrm{~m}[\mathrm{dm}$ centered at $3.075 \mathrm{ppm}, J=12.5 \mathrm{~Hz}], 2 \mathrm{H}), 2.33(\mathrm{td}, J=$ 11.7, 3.0 Hz, 2H), 2.20-2.04 (m, 4H). $\left.{ }^{13} \mathrm{C} \mathrm{NMR} \mathrm{(100} \mathrm{MHz,} \mathrm{CD}_{3} \mathrm{OD}\right): \delta$ 148.65, 148.28, 
140.51, 132.00 (2C), 129.66 (2C), 129.65 (2C), 127.53, 126.10 (broad and small), 122.04, 116.36 (2C), 63.10, 59.05, 52.59 (2C), 32.68 (broad, 2C), 32.66. HRMS (ESI, MeOH) Exact mass calculated for $\mathrm{C}_{21} \mathrm{H}_{26} \mathrm{~N}_{5}[\mathrm{M}+\mathrm{H}]^{+}$: 348.21827, found: 348.2179 ; exact mass calculated for $\mathrm{C}_{21} \mathrm{H}_{25} \mathrm{~N}_{5} \mathrm{Na}[\mathrm{M}+\mathrm{Na}]^{+}: 370.20022$, found: 370.1995 ; exact mass calculated for $\mathrm{C}_{21} \mathrm{H}_{25} \mathrm{~N}_{5} \mathrm{~K}$ $[\mathrm{M}+\mathrm{K}]^{+}: 386.17415$, found: 386.1751 .

(22): ${ }^{1} \mathrm{H}$ NMR (300 MHz, $\mathrm{CD}_{3} \mathrm{OD}$ ): $\delta$ 7.91-7.77 (broad envelope which topped at $7.83 \mathrm{ppm}$, $1 \mathrm{H}$ ), 7.43 (half part of an $\mathrm{A}_{2} \mathrm{X}_{2}$ system, 2H), 7.23 (half part of an $\mathrm{A}_{2} \mathrm{X}_{2}$ system, 2H), 7.17 (broadened half part of an $\mathrm{A}_{2} \mathrm{X}_{2}$ system, 2H), 6.75 (half part of an $\mathrm{A}_{2} \mathrm{X}_{2}$ system, 2H), 4.954.70 (m partly superimposed with the signal of water, $1 \mathrm{H}), 4.22(\mathrm{~s}, 2 \mathrm{H}), 4.01(\mathrm{~s}, 2 \mathrm{H}), 3.73-$ $3.48(\mathrm{~m}, 2 \mathrm{H}), 3.34-3.08(\mathrm{~m}, 2 \mathrm{H}), 2.51-2.24(\mathrm{~m}, 4 \mathrm{H}) .{ }^{13} \mathrm{C} \mathrm{NMR}\left(75 \mathrm{MHz}, \mathrm{CD}_{3} \mathrm{OD}\right): \delta 151.30$, 147.90, 139.70, 133.55 (broad, 2C), 132.74 (2C), 131.69 (2C), 122.80 (broad and small), 121.31, 117.75, 116.12 (2C), 61.79 (broad and small), 56.35 (broad and small), 51.61 (broad and small, 2C), 31.95, 30.75 (broad and small, 2C). HRMS (ESI, MeOH) Exact mass calculated for $\mathrm{C}_{21} \mathrm{H}_{25} \mathrm{~N}_{5}{ }^{79} \mathrm{Br}[\mathrm{M}+\mathrm{H}]^{+}: 426.12878$, found: 426.1286; exact mass calculated for $\mathrm{C}_{21} \mathrm{H}_{24} \mathrm{~N}_{5} \mathrm{Na}^{79} \mathrm{BrNa}[\mathrm{M}+\mathrm{Na}]^{+}$: 448.11073, found: 448.1101; exact mass calculated for $\mathrm{C}_{21} \mathrm{H}_{24} \mathrm{~N}_{5}{ }^{79} \mathrm{BrK}[\mathrm{M}+\mathrm{K}]^{+}: 464.08467$, found: 464.0852 . M.P.: $153.7-156.0{ }^{\circ} \mathrm{C}$.

(23): ${ }^{1} \mathrm{H} \mathrm{NMR}\left(400 \mathrm{MHz}, \mathrm{CDCl}_{3}\right): \delta 7.17$ (half part of an $\mathrm{A}_{2} \mathrm{X}_{2}$ system, $\left.2 \mathrm{H}\right), 7.13(\mathrm{~s}, 1 \mathrm{H})$, 7.07 (half part of an $\mathrm{A}_{2} \mathrm{X}_{2}$ system, 2H), 6.84 (half part of an $\mathrm{A}_{2} \mathrm{X}_{2}$ system, 2H), 6.64 (half part of an $\mathrm{A}_{2} \mathrm{X}_{2}$ system, 2H), $4.40(\mathrm{tt}, J=11.7,4.2 \mathrm{~Hz}, 1 \mathrm{H}), 4.01(\mathrm{~s}, 2 \mathrm{H}), 3.79(\mathrm{~s}, 3 \mathrm{H}), 3.74-3.50$ (broad envelope which topped at $3.63 \mathrm{ppm}, 2 \mathrm{H}), 3.42(\mathrm{~s}, 2 \mathrm{H}), 3.03-2.93$ (m [dm centered at $2.98 \mathrm{ppm}, J=11.5 \mathrm{~Hz}], 2 \mathrm{H}), 2.15-2.05(\mathrm{~m}, 4 \mathrm{H}), 2.03-1.90(\mathrm{~m}, 2 \mathrm{H}) .{ }^{13} \mathrm{C} \mathrm{NMR}(75 \mathrm{MHz}$, $\left.\mathrm{CDCl}_{3}\right): \delta 158.23,147.94,145.54,131.22,130.24$ (2C), 129.72 (2C), 127.82, 118.82, 114.93 (2C), 114.01 (2C), 62.30, 58.29, 55.28, 52.02 (2C), 32.71 (2C), 31.48. HRMS (ESI, $\mathrm{MeOH} / \mathrm{CH}_{2} \mathrm{Cl}_{2}$ : 90/10) Exact mass calculated for $\mathrm{C}_{22} \mathrm{H}_{27} \mathrm{~N}_{5} \mathrm{ONa}[\mathrm{M}+\mathrm{Na}]^{+}$: 400.21078, found: 400.2111 . M.P.: $140.5-142.0^{\circ} \mathrm{C}$.

(24): ${ }^{1} \mathrm{H}$ NMR (300 MHz, $\left.\mathrm{CDCl}_{3}\right): \delta 7.81$ (ddd, $\left.J=8.0,1.2,0.5 \mathrm{~Hz}, 1 \mathrm{H}\right), 7.59-7.50(\mathrm{~m}, 2 \mathrm{H})$, 7.45-7.37 (m, $3 \mathrm{H}$ with a half part of an $\mathrm{A}_{2} \mathrm{X}_{2}$ system $(2 \mathrm{H})$ at $\left.7.42 \mathrm{ppm}\right), 7.18(\mathrm{t}, J=0.7 \mathrm{~Hz}$, $1 \mathrm{H}$ ), 7.14 (half part of an $\mathrm{A}_{2} \mathrm{X}_{2}$ system coupled with $\mathrm{CH}_{2}, J=0.6 \mathrm{~Hz}, 2 \mathrm{H}$ ), 4.42 (tt, $J=11.6$, $4.3 \mathrm{~Hz}, 1 \mathrm{H}), 4.02(\mathrm{~s}, 2 \mathrm{H}), 3.83(\mathrm{~s}, 2 \mathrm{H}), 2.96-2.84$ (m [dm centered at $2.90 \mathrm{ppm}, J=12.1 \mathrm{~Hz}$ ], 2H), 2.25 (ddd, $J=11.9,11.7,2.5 \mathrm{~Hz}, 2 \mathrm{H}), 2.16-2.04(\mathrm{~m}, 2 \mathrm{H}), 2.03-1.86$ (m [nearly qdd, $J=$ 11.7, 4.0, 1.0 Hz], 2H). ${ }^{13} \mathrm{C} \mathrm{NMR}\left(75 \mathrm{MHz}, \mathrm{CDCl}_{3}\right): \delta 149.81,146.79,138.07,133.65$, 132.42 , 131.71 (2C), 130.81, 130.50 (2C), 128.14, 124.47, 120.39, 118.92, 58.80, 58.07, 
52.28 (2C), 32.67 (2C), 31.78. LC-MS: 458.2 [M+2H]. HRMS (ESI, $\mathrm{MeOH} / \mathrm{CH}_{2} \mathrm{Cl}_{2}$ : 90/10) Exact mass calculated for $\mathrm{C}_{21} \mathrm{H}_{23} \mathrm{~N}_{5} \mathrm{O}_{2}{ }^{79} \mathrm{Br}[\mathrm{M}+\mathrm{H}]^{+}$: 456.10296, found: 456.1032; exact mass calculated for $\mathrm{C}_{21} \mathrm{H}_{22} \mathrm{~N}_{5} \mathrm{O}_{2}{ }^{79} \mathrm{BrNa}[\mathrm{M}+\mathrm{Na}]^{+}$: 478.08491, found: 478.0851; Exact mass calculated for $\mathrm{C}_{21} \mathrm{H}_{22} \mathrm{~N}_{5} \mathrm{O}_{2}{ }^{79} \mathrm{BrK}[\mathrm{M}+\mathrm{K}]^{+}$: 494.05884, found: 494.0585. M.P.: 122.0$123.6^{\circ} \mathrm{C}$.

(25): ${ }^{1} \mathrm{H}$ NMR $\left(300 \mathrm{MHz}, \mathrm{CDCl}_{3}\right): \delta 8.22$ (dddt, $\left.J=2.2,1.7,0.5,0.4 \mathrm{~Hz}, 1 \mathrm{H}\right), 8.12$ (dddt, $J=$ 8.2, 2.3, 1.1, $0.5 \mathrm{~Hz}, 1 \mathrm{H}$ ), 7.67 (dddt, $J=7.6,1.7,1.1,0.6 \mathrm{~Hz}, 1 \mathrm{H}$ ), 7.50 (ddd, $J=8.1,7.6,0.4$ $\mathrm{Hz}, 1 \mathrm{H}$ ), 7.42 (half part of an $\mathrm{A}_{2} \mathrm{X}_{2}$ system, 2H), $7.21(\mathrm{t}, J=0.7 \mathrm{~Hz}, 1 \mathrm{H}), 7.14$ (half part of an $\mathrm{A}_{2} \mathrm{X}_{2}$ system coupled with $\left.\mathrm{CH}_{2}, J=0.6 \mathrm{~Hz}, 2 \mathrm{H}\right), 4.46$ (tt, $\left.J=11.4,4.2 \mathrm{~Hz}, 1 \mathrm{H}\right), 4.03(\mathrm{~s}, 2 \mathrm{H})$, $3.63(\mathrm{~s}, 2 \mathrm{H}), 3.04-2.91(\mathrm{~m}[\mathrm{dm}$ centered at $2.97 \mathrm{ppm}, J=12.1 \mathrm{~Hz}], 2 \mathrm{H}), 2.24(\mathrm{td}, J=11.8,2.5$ $\mathrm{Hz}, 2 \mathrm{H}), 2.20-2.11(\mathrm{~m}, 2 \mathrm{H}), 2.11-1.97$ (m, 2H). ${ }^{13} \mathrm{C} \mathrm{NMR}\left(75 \mathrm{MHz}, \mathrm{CDCl}_{3}\right): \delta$ 148.44, $146.84,140.75,138.07,134.77,131.70$ (2C), 130.50 (2C), 129.27, 123.51, 122.36, 120.39, 118.97, 61.69, 58.05, 52.24 (2C), 32.61 (2C), 31.77. LC-MS: 458.2 [M+2H]. HRMS (ESI, $\mathrm{CH}_{2} \mathrm{Cl}_{2}$ / MeOH: 90/10) Exact mass calculated for $\mathrm{C}_{21} \mathrm{H}_{22} \mathrm{~N}_{5} \mathrm{O}_{2}{ }^{79} \mathrm{BrNa}[\mathrm{M}+\mathrm{Na}]^{+}: 478.08491$, found: 478.0851; exact mass calculated for $\mathrm{C}_{21} \mathrm{H}_{23} \mathrm{~N}_{5} \mathrm{O}_{2}{ }^{79} \mathrm{Br}[\mathrm{M}+\mathrm{H}]^{+}$: 456.10296, found: 456.1024. M.P.: $122.0-123.6^{\circ} \mathrm{C}$.

(26): ${ }^{1} \mathrm{H}$ NMR (400 MHz, $\mathrm{CDCl}_{3}$ ): $\delta 7.99$ (half part of an $\mathrm{A}_{2} \mathrm{X}_{2}$ system, $2 \mathrm{H}$ ), 7.44-7.38 (two half parts of $\mathrm{A}_{2} \mathrm{X}_{2}$ systems at 7.42 and $7.40 \mathrm{ppm}, 4 \mathrm{H}$ ), 7.18 (broad s, 1H), 7.14 (half part of an $\mathrm{A}_{2} \mathrm{X}_{2}$ system, 2H), $4.44(\mathrm{tt}, J=11.5,4.4 \mathrm{~Hz}, 1 \mathrm{H}), 4.03(\mathrm{~s}, 2 \mathrm{H}), 3.91(\mathrm{~s}, 3 \mathrm{H}), 3.59$ (broad s, 2H), 3.04-2.92 (m [dm centered at $2.98 \mathrm{ppm}, J=11.8 \mathrm{~Hz}], 2 \mathrm{H}), 2.27-2.09(\mathrm{~m}, 4 \mathrm{H}), 2.03$ (nearly qd, $J=12.0,3.6 \mathrm{~Hz}, 2 \mathrm{H}) .{ }^{13} \mathrm{C} \mathrm{NMR}\left(75 \mathrm{MHz}, \mathrm{CDCl}_{3}\right): \delta 166.98,146.80,143.65$ (broad and small), 138.09, 131.71 (2C), 130.50 (2C), 129.69 (2C), 129.18 (broad and small), 128.75 (2C), 120.40, 118.94, 62.30, 58.16, 52.28 (broad, 2C), 52.09, 32.67 (broad, 2C), 31.78. LC-MS: 469.3 [M+H]. HRMS (ESI, $\mathrm{MeOH} / \mathrm{CH}_{2} \mathrm{Cl}_{2}$ : 90/10) Exact mass calculated for $\mathrm{C}_{23} \mathrm{H}_{25} \mathrm{~N}_{4} \mathrm{O}_{2}{ }^{79} \mathrm{BrNa}[\mathrm{M}+\mathrm{Na}]^{+}$: 491.10531, found: 491.1057; exact mass calculated for $\mathrm{C}_{23} \mathrm{H}_{26} \mathrm{~N}_{4} \mathrm{O}_{2}{ }^{79} \mathrm{Br}[\mathrm{M}+\mathrm{H}]^{+}$: 469.12336, found: 469.1232; exact mass calculated for $\mathrm{C}_{23} \mathrm{H}_{25} \mathrm{~N}_{4} \mathrm{O}_{2}{ }^{79} \mathrm{BrK}[\mathrm{M}+\mathrm{K}]^{+}:$507.07925, found: 507.0793. M.P.: 122.0-123.6 ${ }^{\circ} \mathrm{C}$.

(27): ${ }^{1} \mathrm{H}$ NMR (300 MHz, DMSO-d ${ }_{6}$ ): $\delta 7.96$ (broad s [t after improving the resolution, $J=$ $0.6 \mathrm{~Hz}], 1 \mathrm{H}$ ), 7.90 (half part of an $\mathrm{A}_{2} \mathrm{X}_{2}$ system, 2H), 7.51-7.42 (two half parts of $\mathrm{A}_{2} \mathrm{X}_{2}$ systems at 7.48 and $7.45 \mathrm{ppm}, 4 \mathrm{H}$ ), 7.22 (half part of an $\mathrm{A}_{2} \mathrm{X}_{2}$ system coupled with $\mathrm{CH}_{2}, J=$ $0.6 \mathrm{~Hz}, 2 \mathrm{H}$ ), 4.44 (tt, $J=10.3,5.2 \mathrm{~Hz}, 1 \mathrm{H}$ ), 3.96 (s, 2H), 3.59 (s [above the broad envelope due to the signal of water], $2 \mathrm{H}$ ), 2.94-2.82 (m [dm centered at $2.88 \mathrm{ppm}, J=11.8 \mathrm{~Hz}$ ], 2H), 
$2.17(\mathrm{td}, J=11.2,3.3 \mathrm{~Hz}, 2 \mathrm{H}), 2.07-1.88(\mathrm{~m}, 4 \mathrm{H}) .{ }^{13} \mathrm{C}$ NMR $\left(75 \mathrm{MHz}, \mathrm{DMSO}-\mathrm{d}_{6}\right): \delta 167.16$, 145.15, 143.58, 138.96, 131.14 (2C), 130.72 (2C), 129.44 (broad and small), 129.19 (2C), 128.65 (2C), 120.63, 119.14, 61.16, 57.11, 51.53 (2C), 31.91 (2C), 30.55. LC-MS: 457.2 [M+2]. HRMS (ESI, MeOH / $\mathrm{CH}_{2} \mathrm{Cl}_{2}$ : 90/10) Exact mass calculated for $\mathrm{C}_{22} \mathrm{H}_{23} \mathrm{~N}_{4} \mathrm{O}_{2}{ }^{79} \mathrm{BrNa}$ $[\mathrm{M}+\mathrm{Na}]^{+}$: 477.08966, found:477.090; exact mass calculated for $\mathrm{C}_{22} \mathrm{H}_{24} \mathrm{~N}_{4} \mathrm{O}_{2}{ }^{79} \mathrm{Br}[\mathrm{M}+\mathrm{H}]^{+}$: 455.10771, found: 455.1076; exact mass calculated for $\mathrm{C}_{22} \mathrm{H}_{22} \mathrm{~N}_{4} \mathrm{O}_{2}{ }^{79} \mathrm{BrNa}_{2}[\mathrm{M}-\mathrm{H}+2 \mathrm{Na}]^{+}$: 499.0716, found: 499.0716 . M.P.: $122.0-123.6^{\circ} \mathrm{C}$.

(28): ${ }^{1} \mathrm{H}$ NMR (300 MHz, $\mathrm{CDCl}_{3}$ ): $\delta 8.18$ (half part of an $\mathrm{A}_{2} \mathrm{X}_{2}$ system, $2 \mathrm{H}$ ), 7.62 (half part of an $\mathrm{A}_{2} \mathrm{X}_{2}$ system, 2H), 7.51 (half part of an $\mathrm{A}_{2} \mathrm{X}_{2}$ system coupled with $\mathrm{CH}_{2}, J=0.7 \mathrm{~Hz}, 2 \mathrm{H}$ ), 7.18 (broad s [t after improving the resolution, $J=0.7 \mathrm{~Hz}$ ], 1H), 7.02 (half part of an $\mathrm{A}_{2} \mathrm{X}_{2}$ system coupled with $\left.\mathrm{CH}_{2}, J=0.6 \mathrm{~Hz}, 2 \mathrm{H}\right), 4.44$ (tt, $\left.J=11.3,4.5 \mathrm{~Hz}, 1 \mathrm{H}\right), 4.02(\mathrm{~s}, 2 \mathrm{H}), 3.63$ $(\mathrm{s}, 2 \mathrm{H}), 3.02-2.90(\mathrm{~m}[\mathrm{dm}$ centered at $2.96 \mathrm{ppm}, J=12.1 \mathrm{~Hz}], 2 \mathrm{H}), 2.24(\mathrm{td}, J=11.7,2.5 \mathrm{~Hz}$, 2H), 2.21-1.97 (m, 4H). ${ }^{13} \mathrm{C}$ NMR (100 MHz, $\left.\mathrm{CDCl}_{3}\right): \delta 147.29,146.80,146.23,138.76$, 137.70 (2C), 130.83 (2C), 129.29 (2C), 123.63 (2C), 119.01, 91.77, 61.82, 58.01, 52.33 (2C),

32.62 (2C), 31.88. HRMS (ESI, $\mathrm{CH}_{2} \mathrm{Cl}_{2} / \mathrm{MeOH}$ : 90/10) Exact mass calculated for $\mathrm{C}_{21} \mathrm{H}_{23} \mathrm{~N}_{5} \mathrm{O}_{2} \mathrm{I}[\mathrm{M}+\mathrm{H}]^{+}:$504.0891, found: 504.0893; exact mass calculated for $\mathrm{C}_{21} \mathrm{H}_{22} \mathrm{~N}_{5} \mathrm{O}_{2} \mathrm{INa}$ $[\mathrm{M}+\mathrm{Na}]^{+}:$526.07105, found: 526.0706.

(29): ${ }^{1} \mathrm{H}$ NMR (400 MHz, $\mathrm{CDCl}_{3}$ ): $\delta 8.18$ (half part of an $\mathrm{A}_{2} \mathrm{X}_{2}$ system, $2 \mathrm{H}$ ), 7.51 (half part of an $\mathrm{A}_{2} \mathrm{X}_{2}$ system, 2H), 7.43 (half part of an $\mathrm{A}_{2} \mathrm{X}_{2}$ system, $2 \mathrm{H}$ ), 7.22 (half part of an $\mathrm{A}_{2} \mathrm{X}_{2}$ system, 2H), 7.18 (broad s, 1H), 4.44 (tt, $J=11.5,4.4 \mathrm{~Hz}, 1 \mathrm{H}), 4.08$ (s, 2H), 3.63 (s, 2H), 3.00-2.91 (m [dm centered at $2.96 \mathrm{ppm}, J=12.2 \mathrm{~Hz}], 2 \mathrm{H}), 2.24(\mathrm{td}, J=11.8,2.4 \mathrm{~Hz}, 2 \mathrm{H})$, 2.19-2.11 (m, 2H), 2.11-1.99 (m, 2H). ${ }^{13} \mathrm{C} \mathrm{NMR}$ (75 MHz, $\left.\mathrm{CDCl}_{3}\right): \delta 147.30,146.84,146.24$, 139.97, 132.42 (2C), 129.30 (2C), 128.77 (2C), 123.64 (2C), 120.35, 119.08, 83.47, 77.07, 61.82, 58.01, 52.34 (2C), 32.62 (2C), 32.27. HRMS (ESI, $\mathrm{CH}_{2} \mathrm{Cl}_{2} / \mathrm{MeOH}$ : 90/10) Exact mass calculated for $\mathrm{C}_{23} \mathrm{H}_{24} \mathrm{~N}_{5} \mathrm{O}_{2}[\mathrm{M}+\mathrm{H}]^{+}: 402.19245$, found:402.1928; exact mass calculated for $\mathrm{C}_{23} \mathrm{H}_{23} \mathrm{~N}_{5} \mathrm{O}_{2} \mathrm{Na}[\mathrm{M}+\mathrm{Na}]^{+}$: 424.17439 , found: 424.1742 .

\section{Biological assays}

Trypan Blue enumerations were done on MCF-7 cells plated in 24 wells plates in 1\% FCS RPMI-1640 medium. Cells were treated with the corresponding compound's concentration range for $24 \mathrm{~h}$, trypsinized and stained with Trypan Blue, before being counted on Malassez counting chamber. 
For BRET assays, plasmids encoding for the donor and acceptor fusion proteins (respectively RLucPuma and eYFP-Bcl-xL) were co-transfected in MCF7 cells using Lipofectamine 2000 (Thermofisher) at $200 \mathrm{ng}$ for the donor and $1.5 \mu \mathrm{g}$ for the acceptor per well of 6 well plate. Cells were re-seeded $24 \mathrm{~h}$ later in 96-wells white plates for $24 \mathrm{~h}$ before being treated with the molecules of interest for $16 \mathrm{~h}$. After a round of PBS washing, BRET measurements were acquired with a Mithras LB940 microplate reader (Berthold) using coelenterazine $\mathrm{H}$ (Interchim) as luciferase substrate ( $5 \mu \mathrm{M}$ final molarity). Calculations were done as previously described [3].

Flow cytometry analysis were realized on Hela cells treated or not with corresponding compound (10 $\mu \mathrm{M}, 24 \mathrm{~h})$. After harvesting, cells were fixed and permeabilized using eBioscience Foxp3/Transcription Factor Fixation/Permeabilization Concentrate and Diluent kit (ThermoFisher scientific, ref: 00-5521). Labellings were done using cleaved caspase 3 rabbit mAB Alexa Fluor 647 conjugate (Cell Signaling, ref: 9602) and Alexa Fluor 647 Mouse anti-Cytochrome c mAB (BD Pharmingen, ref: 558709).

\section{Molecular modeling/docking studies}

\section{Docking of compound 15}

Compound 15 was docked using LigandFit v2.4, as implemented in Discovery Studio v17.1 (Biovia, Dassault Systemes, San Diego, CA). The coordinates of cocrystalized Bcl-xL with compound $\mathbf{A - 2}$ was used (PDB: 3QKD) [9]. The explored binding site encompassed all $\boldsymbol{A}-\mathbf{2}$ molecule and extended several $\AA$ beyond, making up about $1800 \AA^{3}$. The CFF force field was used for docking, with a softened Lennard-Jones potential, a non bonded cutoff distance of $10 \AA$, and distance dependant dielectric. Rigid-body minimization was performed during and after pose docking. About 1600 poses were generated, which clusterized roughly in two sites. The first is located between F97 and L130, the second between E96 and Y195 (Supp. Mat. Fig 1). Scoring functions used to estimate ligand affinity (Ligscore2_CFF, PMF, PLP2, Ludi, DOCK_SCORE), as well as binding energy calculated with CHARMM v40.1 marked out the second as the most probable binding site for this ligand. Optimization of the poses was then performed through energy minimization, allowing protein side chains to conformational adaptation. Water molecules as possible bridges for hydrogen bonding were added manually.

Docking of compound $\mathbf{1 5}$ in presence of PUMA was performed using LigandFit, with the same parameters as described previously [7c] , but we used here NMR-derived structure of Bcl-xL/PUMA (PDB : 2M04) [15]. Briefly, a CFF energy grid was defined with $10 \AA$ extension from the binding site of $800 \AA^{3}$, and an energetic penalty of $150 \mathrm{kcal} / \mathrm{mol} /$ atom was set outside the binding site. A softened potential energy was used, with distance dependant dielectric constant of 1 . After docking, each pose and binding site (ligand-receptor complex) were optimized through energy minimization (6000 
steps of steepest descent with CHARMm force field). The eighth conformer of the NMR ensemble was chosen because it is the less perturbed by the filling of compound's cavity.

\section{Molecular dynamics}

The modelled ternary complex (Bcl-xL/PUMA/compound X) was inserted in a water box of $52 \times 56 \times$ $68 \AA$ in explicit periodic boundary conditions, consisting of 5820 water molecules, 27 sodium et 15 chloride ions to equilibrate the system. Optimization of the solvent molecules was performed by 6000 steps of steepest descent energy minimization, keeping the ternary complex fixed. Then the ensemble was again subjected to energy minimization (5000 steps of steepest descent then adopted Newton Raphson), heating ( 200 ps from 50 to $300 \mathrm{~K}$ ), and equilibration (200 ps at $300 \mathrm{~K}$ ). The production was performed using namd v2.9 in NPT conditions, with a timestep of $2 \mathrm{fs}$ at $300 \mathrm{~K}$. The non bond pairlist distance was set to $14 \AA$, the cut off to $12 \AA$ and a switching distance of $10 \AA$. A multiple timestepping integration was used, with a mollified impulse method (MOLLY). A Langevin dynamics was used for the temperature control, and a Langevin piston for the pressure control. All hydrogen-atoms bond were kept rigid (SHAKE), and the SETTLE algorithm was used for water molecules.

Secondary structure of PUMA during the trajectory was assessed via the Define Secondary Structure of Proteins algorithm (DSSP) $[17,18]$, using a perl script provided by Biovia.

\section{Conclusions}

We have discovered new molecules which are able, for the first time, to disrupt the strong interaction between the pro-apoptotic protein PUMA and its anti-apoptotic counterpart BCl-xL. Based on SAR studies, combined with extensive molecular docking and dynamics experiments, we could propose a new mechanism by which a small molecule can advantageously perturb the interaction of bigger protein partners, as a sand in the gears. Such "bottle opener-type" strategy should be promising in other protein-protein interactions, particularly when one of the binding entity is an intrinsically disordered protein, or conditionally structured, as PUMA. Examples are becoming more and more frequent in many crucial biological pathways, and a means to tackle these complex partnerships is very timely.

\section{Conflicts of interest}

There are no conflicts to declare.

\section{Supplementary Material}


Electronic Supplementary Information (ESI) available: [Molecular modelling Figs S1 and S2 plus complete experimental procedures and characterisation for new compounds, with copies of the ${ }^{1} \mathrm{H}$ and ${ }^{13} \mathrm{C}$ NMR spectra]. See DOI: $\mathrm{xxxxx}$

\section{Acknowledgements}

We thank Chemveda Life Sciences for providing laboratory facility for carrying these research experiments. This research has been performed also as part of the Indo-French "Joint Laboratory for Natural Products and Synthesis towards Affordable Health". We thank CSIR, CNRS and University of Rennes 1 for their support. We thank CRMPO (University of Rennes 1) for the mass spectra analysis. Financial support by the "Ligue contre le Cancer, Conseil Interrégional Grand Ouest" is gratefully acknowledged.

\section{Notes and references}

[1] D. Hanahan, R. A. Weinberg, Hallmarks of cancer: the next generation, Cell, 144 (2011), 646-674.

[2] For selected recent reviews see: (a) M. J. Roy, A. Vom, P. E. Czabotar, G. E. Lessene, Cell death and the mitochondria: therapeutic targeting of the $\mathrm{BCl}-2$ family-driven pathway, Brit. J. Pharmacol., 171 (2014), 1973-1987; (b) J. Belmar, S. W. Fesik, Small molecule Mcl-1 inhibitors for the treatment of cancer, Pharmacol. \& Therapeutics 145 (2015), 76-84; (c) E. J. Hennessy, Selective inhibitors of Bcl-2 and $\mathrm{Bcl}-\mathrm{x}_{\mathrm{L}}$ : Balancing antitumor activity with on-target toxicity, Bioorg. Med. Chem. Lett. 26 (2016), 2105-2114; (d) J. L. Yap, L. Chen, M. E. Lanning, S. Flechter, Expanding the cancer arsenal with targeted therapies: disarmament of the antiapoptotic Bcl-2 proteins by small molecules, J. Med. Chem., 60 (2017) 821-838; (e) A. Ashkenazi, W. J. Fairbrother, J. D. Leverson, A. J. Souers, From basic apoptosis discoveries to advanced selective BCl-2 family inhibitors, Nat. Rev. Drug Discov., 16 (2017) 273-284 and references cited therein.

[3] J. Pécot, L. Maillet, J. Le Pen, C. Vuillier, S. C. Trécesson, A. Fétiveau, K. A. Sarosiek, F. J. Bock, F. Braun, A. Letai, S. W. G. Tait, F. Gautier, P. P. Juin, Tight sequestration of BH3 proteins by $\mathrm{Bcl}-\mathrm{xL}$ at subcellular membranes contributes to apoptotic resistance, Cell Rep. 17 (2016), 3347-3358.

[4] G. Lessene, P. E. Czabotar, B. E. Sleebs, K. Zobel, K. N. Lowes, J. M. Adams, J. B. Baell, P. M. Colman, K. Deshayes, W. J. Fairbrother, J. A. Flygare, P. Gibbons, W. J. Kersten, S. Kulasegaram, R. M. Moss, J. P. Parisot, B. J. Smith, I. P. Street, H. Yang, D. C. Huang, K. G. Watson, Structure-guided design of a selective Bcl-X(L) inhibitor, Nat. Chem. Biol. 9 (2013), 390-397.

[5] B. Ku ,C. Liang, J. U., B. H. Oh, Evidence that inhibition of Bax activation by BCl-2 involves its tight and preferential interaction with the BH3 domain of Bax, Cell Res. 21 (2011) 627-641. 
[6] J. R. Jeffers, E. Parganas, Y. Lee, C. Yang, J. Wang, J. Brennan, K. H. MacLean, J. Han, T. Chittenden, J. N. Ihle, P. J. McKinnon, J. L. Cleveland, G. P. Zambetti, Puma is an essential mediator of p53-dependent and -independent apoptotic pathways, Cancer Cell, 4 (2003) 321328.

[7] (a) D. D. Vo, F. Gautier, P. Juin, R. Grée, Eur. J. Med. Chem., Structure-activity relationship of selected polyphenol derivatives as inhibitors of Bax/Bcl-xL interaction 51 (2012) 286-293; (b) D. D. Vo, F. Gautier, S. Barillé-Nion, P. Juin, N. Levoin, R. Grée, Synthesis of new mixed phenol/heterocyclic derivatives and studies of their activity as inhibitors of $\mathrm{Bax} / \mathrm{Bcl}-\mathrm{xL}$ interaction, Tetrahedron, 70 (2014) 301-311 and 4977; (c) D. D. Vo, F. Gautier, S. Barillé-Nion, P. Juin, N. Levoin, R. Grée, Design, synthesis and biological evaluation of new inhibitors of $\mathrm{Bax} / \mathrm{Bcl}-\mathrm{xL}$ interaction in cancer cells, Bioorg. Med. Chem. Lett. 24 (2014), 1758-1761; (d) N. Levoin, D. D. Vo, F. Gautier, S. Barillé-Nion, P. Juin, O. Tasseau, R. Grée, A combination of in-silico and SAR studies to identify binding hot spots of Bcl-xL inhibitors, Bioorg. Med. Chem. 23 (2015), 1747-1757.

[8] H. M. Shallal, J. S. Faridi, W. A. Russu, Anti-tumor pyrimidinylpiperazines bind to the prosurvival Bcl-2 protein family member Bcl-xL, Biorg. Med. Chem. Lett. 21 (2011), 1325-1328.

[9] B. E. Sleebs, P. E. Czabotar, W. J. Fairbrother, W. D. Fairlie, J. A. Flygare, D. C. S. Huang, W. J. A. Kersten, M. F. T. Koehler, G. Lessene, K. Lowes, J. P. Parisot, B. J. Smith, M. L. Smith, A. J. Souers, I. P. Street, H. Yangg, J. B. Baell, Quinazoline sulfonamides as dual binders of the proteins B-Cell Lymphoma 2 and B-Cell Lymphoma extra long with potent proapoptotic cellbased activity, J. Med. Chem., 54 (2011) 1914-1926.

[10] For recent reviews see: (a) S. J. Agalave, S. R. Maujan, V. S. Pore, Click chemistry: 1,2,3-triazoles as pharmacophores, Chem. As. J., 6 (2011) 2696-2718; (b) K. S. S. Praveena, N. Y. S. Murthy, S. Pal, Syntheses and biological activities of 1,4-disubstituted-1,2,3-triazoles, J. Chem. Pharm. Res. 7 (2015), 506-522; (c) E. Bonandi, M. S. Christodoulou, G. Fumagalli, D. Perdicchia, G. Rastelli, D. Passarella, 1,2,3-Triazole Ring as a Bioisostere in Medicinal Chemistry, Drug Disc. Today 22 (2017), 1572-1581.

[11] (a) K. W. Moore, K. Bonner, E. A. Jones, F. Emms, P. D. Leeson, R. Marwood, S. Patel, M. Rowley, S. Thomas, R. W. Carling, 4-N-linked-heterocyclic piperidine derivatives with high affinity and selectivity for human dopamine $D_{4}$ receptors Biorg. Med. Chem. Lett. 9 (1999), 1285-1290; (b) K. S. England, A. Tumber, T. Krojer, G. Scozzafava, S. S. Ng, M. Daniel, A. Szykowska, K. Che, F. von Delft, N. A. Burgess-Brown, A. Kawamura, C. J. Scofield, P. E. Brennan, Optimisation of a triazolopyridine based histone demethylase inhibitor yields a potent and selective KDM2A (FBXL11) inhibitor, Med. Chem. Commun. 5 (2014), 1879-1886.

[12] (a) B. K. Srivastava, R. Soni, J. Z. Patel, M. Solanki, D. Valani, S. Gupta, B. Mishra, V. Takale, P. Pandya, M. R. Jain, P. R. Patel, Synthesis and in vitro antibacterial activity of novel methylamino piperidinyl oxazolidinones, Bioorg. Med. Chem. Lett. 17 (2007), 5227-5232; (b) 
X. Huang, A. Zhang, D. Chen, Z. Jia, X. Li, 4-Substituted 4-(1H-1,2,3-triazol-1-yl)piperidine: novel C7 moieties of fluoroquinolones as antibacterial agents, Bioorg. Med. Chem. Lett. 20 (2010), 2859-2863.

[13] See for instance: (a) R. H. Newman-Evans, R. J. Simon, B. K. Carpenter, The influence of intramolecular dynamics on branching ratios in thermal rearrangements, J. Org. Chem. 55 (1990), 695-711; (b) Y. Zhang, An efficient synthesis of isotope-labeled PD0331179 and its labeled metabolite, J. Label Compd. Radiopharm, 55 (2012), 419-422; (c) S. Shenawi-Khalil, S. U. Sonavane, Y. Sasson, Synthesis of acetylenes via dehydrobromination using solid anhydrous potassium phosphate as the base under phase-transfer conditions, Tetrahedron Lett. 53 (2012), 2295-2297; (d) M. C. Davis, A. J. Guenthner, C. M. Sahagun, K. R. Lamison, J. T. Rims, J. M. Mabry, Polycyanurate networks from dehydroanethole cyclotrimers: Synthesis and characterization, Polymer, 54 (2013), 6902-6909; (e) G. Henrion, T. E. J. Chavas, X. Le Goff, F. Gagosz, Biarylphosphonite gold(I) complexes as superior catalysts for oxidative cyclization of propynyl arenes into indan-2-ones, Ang. Chem. Int. Ed. 52 (2013), 6277-6282; (f) R. Sang, H-B. Yang, M. Shi, DBU-mediated transformation of arylmethylenecyclopropenes to alkylidenecyclopropanes, Tetrahedron Lett. 54 (2013), 3591-3584; (g) A. M. Haydl, L. J. Hilpert, B. Breit, regioconvergent and enantioselective rhodium-catalyzed hydroamination of internal and terminal alkynes: a highly flexible access to chiral pyrazoles, Chem. Eur. J. 22 (2016), 6547-6551 and references cited therein.

[14] For a general review on click chemistry see: (a) H. C. Kolb, M. G. Finn, K. B. Sharpless, Click Chemistry: diverse chemical function from a few good reactions, Ang. Chem. Int. Ed. 40 (2001), 2004-2021; see also: (b) V. V. Rostovtsev, L. G. Green, K. B. Sharpless, A stepwise Huisgen cycloaddition process: copper(I)-catalyzed regioselective "ligation" of azides and terminal alkynes, Ang. Chem. Int. Ed. 41 (2002), 2596-2599; (c) C. W. Tornoe, C. Christensen, M. Medal, Peptidotriazoles on solid phase: [1,2,3]-triazoles by regiospecific copper(I)catalyzed 1,3-dipolar cycloadditions of terminal alkynes to azides, J. Org. Chem. 67 (2002), 3057-3064; (d) F. Himo, T. Lovell, R. Hilgraf, V. V. Rostovtsev, L. Noodleman, K. B. Sharpless, V. V. Fokin, Copper(I)-catalyzed synthesis of azoles. DFT study predicts unprecedented reactivity and intermediates, J. Am. Chem. Soc. 127 (2005), 210-216; (e) J. C. Loren, A. Krasiński, V. V. Fokin, K. B. Sharpless, NH-1,2,3-triazoles from azidomethyl pivalate and carbamates: base-labile N-protecting groups, Synlett 18 (2005), 2847-2850; (f) J-F. Lutz, Copper-free azide-alkyne cycloadditions: new insights and perspectives, Ang. Chem. Int. Ed. 47 (2008), 2182-2184, and references cited therein. 
[15] A. V. Follis, J. E. Chipuk, J. C. Fischer, M. K. Yun, C. R. Grace, A. Nourse, K. Baran, L. Ou, L. Min, S. W. White, D. R. Green, R. W. Kriwacki, PUMA binding induces partial unfolding within Bcl-xL to disrupt p53 binding and promote apoptosis, Nat. Chem. Biol, 9 (2013), 163-168.

[16] I. Nederpelt, J. Bunnick, A. P. Ijzerman, L. H. Heitman, Kinetic Profile of NeuropeptideReceptor Interactions, Tr. NeuroSci. 39 (2016), 830-839.

[17] W. Kabsch, C. Sander, Dictionnary of protein secondary structure: pattern recognition of hydrogen-bonded and geometrical features, Biopolymers, 22 (1983), 2577-2637.

[18] C. A.F. Andersen, A. G. Palmer, S. Brunak, B. Rost, Continuum secondary structure captures protein flexibility, Structure, 10 (2002), 175-184.

[19] H. A. Orgueira, D. Fokas, Y. Isome, P. C.-M. Chan, C. M. Baldino, Regioselective synthesis of $[1,2,3]$-triazoles catalyzed by $\mathrm{Cu}(\mathrm{I})$ generated in situ from $\mathrm{Cu}(0)$ nanosize activated powder and amine hydrochloride salts, Tetrahedron Lett. 46 (2005), 2911-2914. 